Discussion Paper No. 13-038

\title{
Direct Democracy and Local Public Finances under Cooperative Federalism
}

Zareh Asatryan, Thushyanthan Baskaran, Theocharis Grigoriadis, and Friedrich Heinemann

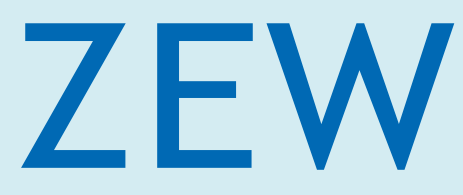

Zentrum für Europäische Wirtschaftsforschung $\mathrm{GmbH}$ Centre for European Economic Research 


\title{
Discussion Paper No. 13-038 \\ Direct Democracy and Local Public Finances under Cooperative Federalism
}

\author{
Zareh Asatryan, Thushyanthan Baskaran, \\ Theocharis Grigoriadis, and Friedrich Heinemann
}

Download this ZEW Discussion Paper from our ftp server:

http://ftp.zew.de/pub/zew-docs/dp/dp13038.pdf

Die Discussion Papers dienen einer möglichst schnellen Verbreitung von neueren Forschungsarbeiten des ZEW. Die Beiträge liegen in alleiniger Verantwortung der Autoren und stellen nicht notwendigerweise die Meinung des ZEW dar. 


\section{Non-technical Summary}

A growing literature studies the role of political institutions in shaping fiscal outcomes. One of the most important differences in political institutions of established democracies is whether fiscal and economic decisions are made by elected representatives or through direct voting. Popular influence over policy making brings fiscal policy closer to the electorate's preferences. If representatives prefer more spending than voters, then direct democracy will constrain public budgets. If voters prefer more spending than representatives, then spending will be higher in political jurisdictions that allow for more direct democracy.

The public choice tradition argues that elected politicians tend to overspend, overtax and to overborrow due to the interests and influence of bureaucrats or special interest groups. Direct democracy may shift power to voters themselves thus alleviating the principle-agent problems. Direct legislation is one mechanism of the fiscal constitution that allows voters to constrain the Leviathan government.

In a federal setting, however, local voters may face particular common-pool disincentives. If the funding of municipalities originates from a "common pool" of country-wide and future taxpayers, voters also welcome overspending on local public goods and services. Voter disincentives may even be larger than those of local politicians. The latter are often constrained by the policies of their countrywide parties. This may result in voters' inaction against constraining the Leviathan or even incentivize them to act as a Leviathan themselves against the taxpayers of other jurisdictions. In this case, direct democracy increases spending.

The present paper tries to answer empirically which of the two perspectives has validity for Germany. It is the first analysis of the link between direct democracy and fiscal outcomes for Germany, an archetypal cooperative federation. Hence, Germany offers an intriguing case of comparison against the existing Swiss and US evidence. 
The starting point of the empirical analysis exploits the variance in the use of voter initiatives at the municipal level in the German State of Bavaria. We have information on all initiatives since the introduction of the right of petitioning for referenda in 1995 . Using an selection on observables approach, we find a negative instantaneous correlation between referenda activity and municipal budgets. This turns positive with increasing lags.

To address the obvious endogeneity problems of the selection on observables approach, the main part of the analysis exploits the discontinuous relationship between municipal population sizes on the one hand and signatures needed to initiate referenda as well as the minimum quorum requirements for referenda to be approved on the other. A regressiondiscontinuity design can be used to identify the causal effect of direct democracy. To safeguard against other exogenous co-treatments that might affect fiscal institutions simultaneously at the same thresholds, we also implement a "difference-in-discontinuity design" by comparing the discontinuities in the pre- and post-reform periods.

The results indicate that in the German federal setting, direct democracy had a significantly positive and robust effect on local government spending and revenue. We estimate the size of effect to be a $10 \%$ average increase in annual per capita municipal spending and revenue. A plausible explanation for this result diverging from the Swiss or US experience is that the cooperative form of federalism in Germany results in strong common-pool disincentives on part of local voters. 


\section{Das Wichtigste in Kürze}

Eine wachsende Literatur befasst sich mit dem Einfluss von politischen Institutionen auf fiskalische Ergebnisse. Einer der wichtigsten Unterschiede zwischen den politischen Institutionen etablierter Demokratien betrifft das Ausmaß der direkten Demokratie. Der unmittelbare Wählereinfluss sollte eine Annäherung der Fiskalpolitik an die Wählerpräferenzen erzwingen. Wenn politische Repräsentanten ein höheres Ausgabeniveau als Wähler bevorzugen, dann sollte direkte Demokratie folglich die Höhe der öffentlichen Haushalte begrenzen. Wenn Wähler ein höheres Ausgabeniveau bevorzugen, dann sollten umgekehrt mit direkter Demokratie größere Budgets einhergehen.

Die Public-Choice-Tradition argumentiert, dass gewählte Politiker übermäßige Ausgaben, Steuern und Schulden präferieren, weil sie von Bürokratie und von Interessengruppen beeinflusst werden. Direkte Demokratie verlagert dann die Macht zu den Wählern selber, was Prinzipal-Agenten-Probleme abmildert. Direkte Gesetzgebung wäre somit ein Mechanismus in einer Fiskalverfassung, der den Wählern hilft, den Leviathan zu begrenzen.

In einem föderalen Umfeld sind Wähler aber möglicherweise besonderen CommonPool-Fehlanreizen ausgesetzt. Wenn die Finanzierung von Kommunen aus einem gemeinsamen Topf (dem "Common Pool") landesweiter und zukünftiger Steuereinnahmen herrührt, dann werden auch Wähler ein übermäßiges Ausgabenniveau zur Bereitstellung lokaler öffentlicher Güter und Dienstleistungen bevorzugen. Diese Fehlanreize können auf der Ebene der Wähler sogar größer als auf der Ebene der lokalen Politiker sein. Letztere sind oft durch die Politiken landesweiter Parteien restringiert. Das kann dazu führen, dass Wähler kein Interesse an der Begrenzung des Leviathan haben oder sogar selber als Leviathan zu Lasten der Steuerzahler anderer Jurisdiktionen auftreten. Dann würde direkte Demokratie ausgabesteigernd wirken.

Dieses Papier versucht für Deutschland empirisch zu beantworten, welche dieser beiden Sichtweisen stichhaltig ist. Es ist der erste Beitrag zum Einfluss von direkter Demokra- 
tie auf fiskalische Ergebnisse für Deutschland, einem typischen Modellfall des kooperativen Föderalismus. Deutschland bietet somit einen interessanten Vergleichsfall zu den Erfahrungen der Schweiz und USA.

Der Ausgangspunkt der empirischen Analyse macht sich die Varianz in der Nutzung von Bürgerbegehren in den Kommunen Bayerns zunutze. Wir verfügen über Informationen über alle Bürgerbegehren seit der Einführung dieses Rechts auf der kommunalen Ebene in Bayern im Jahr 1995. Der Einsatz eines konventionellen Regressionsansatzes ("selection on observables") erbringt eine negative zeitgleiche Korrelation zwischen dem Auftreten von Bürgerbegehren/Bürgerentscheiden und der Höhe der kommunalen Ausgaben. Diese Korrelation wird mit steigendem zeitlichen Abstand positiv.

Um die offensichtlichen Endogenitätsprobleme dieses konventionellen Ansatzes zu berücksichtigen, nutzt der Hauptteil der Analyse die diskontinuierliche Beziehung zwischen Bevölkerungsgröße und den Unterschrifts- und Beteiligungsquoren bei Bürgerbegehren und Bürgerentscheiden aus. Hier kann ein Regression-Discontinuity-Design zur Anwendung kommen, um den kausalen Effekt der direkten Demokratie zu identifizieren. Um dem Problem gleichzeitiger Beeinflussung der Fiskalpolitik durch andere institutionelle Änderungen an der gleichen Sprungstelle zu begegnen, implementieren wir außerdem ein "difference-in-discontinuity design". Dabei wird die Diskontinuität vor und nach der Reform verglichen.

Die Ergebnisse deuten darauf hin, dass unter den Bedingungen des deutschen Föderalismus direkte Demokratie einen signifikant positiven und robusten Effekt auf die Ausgaben und Steuern der Kommunen ausübt. Die Größe des Effekts beläuft sich auf einen Anstieg von durchschnittlich 10\% der Pro-Kopf-Ausgaben. Eine plausible Erklärung für diese stark von den Erfahrungen der Schweiz und USA abweichenden Ergebnisse ist, dass der deutsche kooperative Föderalismus zu starken Common-Pool-Fehlanreizen bei den lokalen Wählern führt. 


\title{
Direct Democracy and Local Public Finances under Cooperative Federalism
}

\author{
Zareh Asatryan (ZEW Mannheim and University of Freiburg) * \\ Thushyanthan Baskaran (University of Göttingen) \\ Theocharis Grigoriadis (Free University of Berlin) \\ Friedrich Heinemann (ZEW Mannheim and University of Heidelberg)
}

June, 2013

\begin{abstract}
This paper exploits the introduction of the right of referenda at the local level in the German state of Bavaria in 1995 to study the fiscal effects of direct democracy. In the first part of the paper, we establish the relationship between referenda activity and fiscal performance by using a new dataset containing information on all 2500 voter initiatives between 1995 to 2011 . This selection on observables approach, however, suffers from obvious endogeneity problems in this application. The main part of the paper exploits population dependent discontinuities in the signature and quorum requirements of referenda to implement a regression discontinuity design (RDD). To safeguard against co-treatments that might affect fiscal outcomes simultaneously at the same thresholds, we validate our results by extending the RDD approach to a difference-in-discontinuity (DiD) design. By studying direct legislation in an archetypical cooperative federation as Germany, our paper extends the literature to a novel institutional setting. The results indicate that in our setting - and in contrast to most of the evidence from Switzerland and the US - direct democracy causes an expansion of local government budgets.
\end{abstract}

Keywords: Direct democracy, fiscal policy, regression discontinuity, Bavaria JEL codes: D72, D78, H70

${ }^{*}$ Corresponding author: Zareh Asatryan, ZEW, L7 1, 68161 Mannheim, Germany; Tel.: (+49)6211235392; Email: asatryan@zew.de

We are grateful to Benny Geys and seminar participants at ZEW Mannheim, University of Mannheim and 2013 meeting of the European Public Choice Society for valuable comments. 


\section{Introduction}

Chronic fiscal imbalances and acute debt crises in the industrialized world have intensified the search for appropriate budgetary institutions. The underlying problem of budgetary decision making in representative democracies has been diagnosed in the seminal work of Shepsle, Weingast and Johnsen in the early 1980s (Shepsle and Weingast, 1981; Weingast et al., 1981): Elected politicians tend to favor their regional or political constituencies in spending decisions while the funding comes from the "common pool" of present and future taxpayers. This asymmetry creates incentives to overspend, overtax and overborrow. While the public finance literature is characterized by a large consensus on this diagnosis, there is less of an agreement on the appropriate therapy. Several institutional treatments have attracted attention ranging from adjustments in budgetary procedures von Hagen, 2002; Hallerberg et al., 2007) to countervailing spending externalities through numerical fiscal rules (Debrun et al. 2008).

A more direct way of addressing the disincentives of representative politicians is direct democracy. Referenda reduce the decision making competencies of elected politicians and shift power to the voters themselves, thereby alleviating possible principle-agentproblems. If representative politicians (in a possible alliance with bureaucrats) disregard the interests of taxpayers in general, the latter may use direct votes to discipline parliaments.

Yet, it cannot be taken for granted that direct democracy will effectively constrain overspending (see literature survey in the following section): Voters face similar commonpool-disincentives as their representatives. Possibly, these disincentives are even larger for local voters than for local politicians. This may hold, for example, if local politicians have a less parochial perspective as a consequence of their membership in a country-wide party. Further disincentives emanate from the incentives of the median voter. With respect to redistributive spending projects it is well known that these are attractive for the median voter if mean income exceeds median income (Meltzer and Richard, 1981). 
From a theoretical standpoint, therefore, there are countervailing arguments on the impact of direct democracy on the size of government. The outcome should also depend on the characteristics of a fiscal constitution and its interaction with direct democracy: Direct voter control has clearly less potential of curbing pork-barrel spending if a jurisdiction heavily relies on vertical or horizontal grants for financing its expenditure. When there is no revenue autonomy at the local level, voters do not decide on their own tax burden and will not be immune against common-pool-disincentives in direct votes.

Therefore, it is desirable to test for the impact of direct democracy in different federal environments. However, the literature on the fiscal impact of direct democracy (surveyed below) is largely limited to Switzerland and the US. The question is whether insights from these countries are informative about the implications of direct democracy under different institutional and cultural conditions. This is where our contribution lies. Our paper is the first to look into the impact of direct democracy in Germany, an archetypical cooperative federation.

We analyze the municipal experience in the federal state of Bavaria, where direct democracy was introduced through a constitutional change in 1995 and where between 1995 and 2011 around 2500 petitions to implement referenda were recorded $\stackrel{1}{1}^{1}$ The case of the German municipalities is an important extension to the literature on direct democracy and fiscal policy. In contrast to Switzerland and the US, direct democracy is a relatively recent institutional innovation for German municipalities. German voters and politicians lack long-run experience with this set of institutions. Furthermore, German federalism is characterized by intensive equalization and joint taxation of all federal layers. To a large extent, municipal revenues depend on fixed shares from country-wide general taxes and on grants from their state. Hence, this federal system entails particular substantive common-pool-disincentives. Germany offers a compelling testing ground to explore the

\footnotetext{
${ }^{1}$ The reason to concentrate on the case of Bavaria is that compared to other German Länder, locallevel direct democratic institutions in Bavaria, although being a relatively recent innovation, are by far the strongest. This is clearly seen in Figure 1. where the total number of initiatives per Land are shown along with the date of the adoption of the local-level direct democratic legislation.
} 
external validity of the numerous studies for the US and Switzerland: does the usual result that direct democracy constrains spending survive in a different federal environment?

Our paper does not only contribute to the literature through its extension toward another distinct federal context. In addition, it offers a credible identification strategy. Here, we follow a recent innovative trend in the empirical public finance literature to exploit population-discontinuities in federal constitutions for identification. Examples along that avenue concern the impact of municipal council size on government spending (Pettersson-Lidbom, 2012, Egger and Köthenbürger, 2010), the impact of politicians' salaries on performance (Gagliarducci and Nannicini, 2013) or tests of the flypaper effect (Dahlberg et al., 2008; Baskaran, 2012). Our contribution is not only the first to apply a regression-discontinuity design (RDD) to study the impact of direct democracy. It also makes use of a RDD-refinement which copes with the criticism from Ade and Freier (2011). These authors point to the problem that, typically, certain population thresholds have simultaneous functions in municipal constitutions. Identical population thresholds affect council size, mayor salary, community status, grants or direct democracy provisions at the same time. Furthermore, municipal population size is not perfectly immune to some manipulation and, hence, not fully exogenous. These two problems may limit a (one-dimensional) causal interpretation of a RDD approach. We deal with this problem by applying a difference-in-discontinuity (DiD) design which exploits the introduction of direct democracy and allows studying the impact of population discontinuities before and after this innovation. Under certain conditions, this RDD-refinement allows filtering out the causal impact of the direct democracy related thresholds.

We first start by studying the relationship between direct democracy in action - that is the actual use of popular referenda in practice - and fiscal outcomes using a novel dataset on 2099 Bavarian municipalities over the period from 1978 to 2011 and employing a standard selection on observables methodology. This methodology, however, might suffer from endogeneity and, therefore, rightly deserves criticism as a naive regression Angrist and Pischke, 2010). Therefore, we exploit in the second step a natural experiment based 
on population thresholds. In contrast to the Swiss or US cases, where the literature has exploited constitutional differences in the direct democratic institutions across cantons or states, we rely on the discontinuous relationship between municipal population size on the one hand and signatures needed to initiate referenda, as well as the minimum quorum requirements for referenda to be approved. We are able to complement the standard RDD by a DiD design through comparing the impact of the discontinuity before and after the introduction of municipal direct democracy in Bavaria in 1995.

The naive regression reveals an instantaneous negative correlation between referenda activity and spending. However, this correlation turns positive with an increasing time lag. These first insights from the selection on observables approach point to the possibility that low spending may provoke voter resistance through initiatives which, after they become effective, increase spending. The application of our causal identification strategy establishes a positive impact of referenda on expenditures and revenues: There are jumps in these variables' levels at the relevant population thresholds. In addition, these jumps are only detectable after the 1995 introduction of municipal direct democracy. Hence, we can be confident that the jumps are not strongly driven by other municipal parameters affected by the population thresholds. Robustness checks confirm the findings.

The remainder of this paper is structured as follows: First, we summarize the literature on direct democracy and fiscal outcomes, followed by a brief summary of the German institutional setting and the Bavarian institutions of direct democracy. Subsequently, we develop our identification strategy and present our empirical results.

\section{Literature review}

Views on how democracy affects fiscal policy have changed over time. When the first modern democracies emerged in the late 19th century, political philosophers believed that popular influence over policy making would cause a substantial rise in redistributive public 
spending ${ }^{2}$ As the income distribution is right-skewed in most countries, the majority of the electorate presumably prefers large redistributive transfers. In a democratic system, therefore, public spending and thus taxation should be relatively high. Indeed, this view on how democracy will affect fiscal policy is supported by theoretical contributions that employ the median voter model (Kenny, 1978; Meltzer and Richard, 1981).

As a commitment against expropriatory taxation and, more generally, to account for the drawbacks of democracy, many countries complement popular sovereignty with various checks and balances. One of those checks is a representative form of government. The logic is that through delegation of decision-making power to elected representatives, some unintended negative side-effects of democracy may be avoided. Elected representatives, it is often argued, are more educated, better informed and balanced than the average voter. Therefore, the policies they choose will reflect these characteristics.

However, the alleged superiority of representative democracy in preventing expropriatory taxation has recently been questioned by scholars of political economics. The continuous increase in the size of government since the early 20th century onward led researchers to claim that representative democracies face an inherent spending bias. Baumol and Bowen (1966), for example, argue that productivity growth is persistently smaller than the growth of wages in the public sector. One reason for this phenomenon could lie in the inability of politicians to deny public sector employees high wages. Niskanen (1971) focuses on the bureaucracy in representative democracies. He argues that bureaucrats prefer to have large budgets, because they are associated with more prestige and facilitate higher salaries. Politicians in representative democracies, on the other hand, have too few incentives to deny the bureaucracy the funds it requests. A third set of authors states that public spending will be higher in representative forms of government because of common pool problems. Weingast et al. (1981), in particular, argue that rep-

\footnotetext{
${ }^{2}$ Consider for example the famous quote that is often attributed to the 19th century philosopher and lawyer Alexander Fraser Tytler (according to Niskanen et al. (1980)): "A democracy cannot exist as a permanent form of government. It can only exist until the voters discover that they can vote themselves largesse from the public treasury. From that moment on, the majority always votes for the candidates promising the most benefits from the public treasury, with the result that a democracy always collapses over loose fiscal policy, always followed by a dictatorship."
} 
resentatives have an incentive to vote for higher spending if spending can be targeted to their own constituency while the associated tax hikes affect all constituencies alike $\mathrm{H}^{3}$

The line of thinking about representative democracies culminated in theories - developed chiefly by public choice scholars - that perceive the state as a Leviathan. Rather than discussing if and under what conditions representative government will result in higher spending, Brennan and Buchanan (1980) simply assume that this type of government has an inherent spending bias. In their view, representative democracies are only interested in revenues and public spending. They will choose the highest possible level of taxation, and only desist if stipulations in the fiscal constitution force them to do so. Elections, on the other hand, are in their opinion an ineffective means to control the growth of government.

Given the decisive role of the fiscal constitution identified by Brennan and Buchanan (1980), researchers explored which constitutional features are particularly effective in reigning in the spending bias of representatives. Constitutional features that have been studied are, for example, budget institutions (tax, spending, and borrowing limits) Inman (1998), electoral rules and regime types (Persson and Tabellini, 2004), and fiscal decentralization (Schaltegger and Feld, 2009).

Direct democracy is another feature of the fiscal constitution, whose effect on fiscal policy has been analyzed recently. However, the predictions about the effects of direct democracy on fiscal policy are different in the political economics literature than in those contributions that emphasize the dangers of democracy as such. In the political economics literature, it is argued that direct democracy will limit rather than expand the size of government. While the relevant authors do not dispute that that redistributive spending might be higher in political jurisdictions that have direct democratic institutions, they argue that this effect will be outweighed by the reduction in spending because of voters' improved ability to control the Leviathan (Feld and Kirchgässner, 2001).

\footnotetext{
${ }^{3} \mathrm{~A}$ comprehensive discussion on various sources of inefficiency in representative democracies is offered by Besley and Coate (1998).
} 
Given the countervailing effects, it is an empirical question as to whether direct democracy leads to an expansion or a reduction in the size of government. A growing array of empirical studies have analyzed this question. Most studies rely on cross-sectional variation at the state and/or municipal level in two federations: the United States and Switzerland. For the United States, the results are inconclusive. Some studies find that direct democracy leads to smaller governments (Bails and Tieslau, 2000; Besley and Case, 2003; Blomberg et al., 2004), others find ambiguous results (Farnham, 1990; Matsusaka, 1995; Camobreco, 1998; Matsusaka, 2000; Salvino et al., 2012), and some suggest a positive effect of direct democratic legislation (Zax, 1989, Marschall and Ruhil, 2005, Primo, 2010). A further source of ambiguity is that municipal spending appears to be higher in states with stricter direct democracy, suggesting a correlation between direct democracy and the decentralization of spending (Matsusaka, 1995, 2000).

The studies for Switzerland point toward a negative effect of direct democracy on government size (Pommerehne, 1978; Feld and Kirchgässner, 2001; Feld and Matsusaka, 2003; Funk and Gathman, 2011). As in some of the findings for the US, however, Feld et al. (2008) find that direct democracy induces less centralization, while Galletta and Jametti (2012) argue that the vertical structure of direct democratic institutions also matters and find higher local spending levels in municipalities without fiscal referenda belonging to cantons with fiscal referenda compared to municipalities without direct voting at any of the local or cantonal levels.

Most of these studies do not compare political jurisdictions with representative versus direct democratic legislations. In Switzerland, for example, all cantons have a voter initiative and most have, in addition, a mandatory or an optional referendum. It is therefore not feasible to compare cantons with and without any direct democratic institutions. Feld and Matsusaka (2003) and most other authors circumvent this problem by interpreting lower spending thresholds and smaller number of required signatures as evidence of stronger direct democratic institutions, and, thus, compare political jurisdictions that differ in the ease with which direct democratic elements can be initiated. 
Except for the US and Switzerland, only few countries have been studied by the literature on direct democracy. In fact, the only exception we are aware of is the study by Hinnerich and Pettersson-Lidbom (2012) that compares Swedish municipalities that had direct democratic institutions with those that had a purely representative form of government in the early 20th century. They find that local direct democracy leads to less redistributive spending than representative forms of government. Their interpretation of this finding differs from that of those authors that subscribe to the Leviathan view of government, however. Hinnerich and Pettersson-Lidbom (2012) explain their finding by arguing that elites can capture the political process more easily in direct democratic settings, which in turn causes spending that benefits the poor to decline.

Systematic evidence regarding the relationship between direct democracy and fiscal policy from Germany is non-existent. 4 The reason is presumably that despite widespread demand for more direct democracy from citizens (Feld et al., 2011), such institutions have only recently been introduced in a comprehensive manner at the local level. By focusing on the important state of Bavaria, our paper is hence the first that provides quantitative evidence about the effects of direct democracy on fiscal policy in Germany.

\section{Institutional details}

The roots of direct democracy in Bavaria are in Germany's constitutional revolution in 1918-19 and the emergence of the Weimar Republic (Setala and Schiller, 2012). Due to the failure of the Weimar Republic and the experiences of the Nazi era, the federal and state constitutions of the Federal Republic of Germany had initially been restrictive on direct

\footnotetext{
${ }^{4}$ One exception is a recent study by Blume et al. (2011) that compares Bavarian pre- and post1995 local government expenditures with that of the neighboring Land of Baden-Württemberg where initiatives are allowed since 1956. The analysis, however, remains descriptive in nature due to small number of observations as the local level fiscal data is aggregated to state level. Also, admittedly, the heterogeneity of direct democratic institutions of the two states make them hard to compare. One proof of heterogeneity, for example, is the fact that by 2011 three times more initiatives have happened in Bavaria compared to Baden-Württemberg, where the direct democratic legislation was adopted 40 years earlier (Figure 1). Some of the reasons include intensive restrictions on topics of referenda (more correctly, referenda can be initiated only in certain areas that are listed in in the law in a positive catalogue of allowed topics), more conservative formal requirements of the initiative process etc.
} 
democratic institutions (Eder et al., 2009). Whereas the Basic Law ("Grundgesetz") at the federal level was almost purely representative, the constitutions in seven out of ten Western German states allowed for some elements of direct democracy. The year 1989 and the peaceful collapse of Communism in Eastern Germany mark a turning point: Since German reunification all new states established constitutions with direct democratic elements and the old states adjusted their order. Even though today German voters in all 16 states have the basic right to petition for popular initiatives at the state level, initiating referenda remains very hard. Empirically, direct democracy was hardly used before 1989 in the German states under more restrictive rules: only 27 initiatives had been submitted, out of which only two made it to the popular vote. Both were rejected.

Interestingly, already in this early stage, Bavaria was a front-runner with almost half of the state total number of initiatives (Eder et al., 2009). In the 1990s, the demand for direct democracy increased in all states and, particularly, in Bavaria (Setala and Schiller, 2012); the dominance of the Christian Social Union (CSU) has been identified as one particular motivation for this movement since representative parliaments at state and municipal levels used to be characterized by strong majorities of the CSU. Figure 1 shows the years of adopting local-level direct democratic legislation across German states and the number of total initiatives since adoption.

Until 1995, the use of referenda in Bavaria was limited to the state level, yet with significant barriers for the initiative process. Among other requirements, at the final stage signatures amounting to the $10 \%$ of eligible voters (or around 900,000 signatures) had to be collected in just two weeks time making the signature threshold virtually unachievable (Verhulst and Nijeboer, 2008). In fact, only three state-wide referenda have been held in Bavaria since the Second World War. In 1995, however, popular mobilization occurred due to the efforts of "Mehr Demokratie" ("More Democracy"), a non-governmental association, which started to advertise the significance of direct democracy at the local level already before reunification with increasing efforts in the early 1990s (Premat, 2006). The pro-direct democracy alliance became attractive for opposition parties, social orga- 
nizations and even some CSU politicians that opposed to their party's official policy line. The initiative received strong support by nearly 1.2 million Bavarians in two weeks time comfortably passing the $10 \%$ signature threshold, and was implemented as a referendum in October, 1995 collecting 57.8\% "yes-votes" (Verhulst and Nijeboer, 2008).

As a result, Article 18a was added to the Municipalities Law of the Free State of Bavaria (Gemeindeordnung für den Freistaat Bayern) which defines the direct democratic legislation at the municipal level: Voters can launch an initiative ("Bürgerbegehren") for a referendum ("Bürgerentscheid") with respect to an issue within the competencies of the municipality. Initiatives are not allowed to question the internal organization of the municipal administration, competencies exclusively granted to the mayor by law, the legal affairs of municipal council members, the mayor and municipal employees, and the budget bylaws. An initiative successfully leads to a referendum if it is supported by a sufficient number of signatures from municipal residents. These signature requirements depend on the population size of the municipality, and there is no time limit for collection. Within a month after submitting the application for a referendum, the municipal council has to decide whether the conditions for a lawful referendum are fulfilled. In this case, the referendum has to be conducted no later than three months after the council decision and is implemented under the will of the simple majority. It is important to point out here that an approved referendum has the legal effects of a municipal council decision; it can be reversed only with another referendum on the same question within a year from the first referendum. Thus, the introduction of direct democracy in Bavarian municipalities in 1995 enabled citizens to conditionally substitute the legislative functions of elected municipal council members.

Subsequent to its establishment, local direct democracy flourished in Bavaria and particularly in the first years, when between 1995 and 1999 close to 900 initiatives had taken place (Figure 2 shows the total number of initiatives per Bavarian town, while the annual evolution of initiatives and referenda are shown in Figure 3. This activity was signifi- 
cantly dampened after quorum requirements were introduced to the law in 1999 5 The observation that higher signature or quorum requirements reduce the intensity of direct democratic control is crucial for our identification strategy developed below. It is in line with a general observation for Germany: Higher institutional requirements strongly reduce the number of popular initiatives over all German states (Eder et al., 2009). Nevertheless, in most years since then more than one hundred municipal initiatives take place every year. Overall, in the post-reform period, between 1995 and 2011, there have been around 2500 initiatives in all Bavarian municipalities roughly half of them reaching to the polls.

As in all German States, municipalities in Bavaria are responsible for the provision of important public goods to citizens such as kindergartens, elementary schools, utility and infrastructure facilities, local streets, athletic areas and basic health care.

On the revenue side, Bavarian - like all German - municipalities enjoy some limited degree of tax autonomy: They are able to set the tax rates of property taxes on land and real estate and of a trade tax on local business. For these taxes, the tax bases are uniformly defined nationwide but municipalities are free to decide the tax rate through the definition of a tax multiplier. Nevertheless, municipal finance strongly depends on country- and state-wide revenue sharing and equalization arrangements. Municipalities receive predefined shares of VAT and income taxes without any autonomy to set e.g. surcharges on these country-wide taxes. In addition, Bavarian municipalities depend heavily on both block and special purpose grants received mainly from the state of Bavaria (and to a smaller extent from the federal level). Thus, autonomously set municipal taxes only amount to one quarter of total municipal revenues (Table 1). Grants received from the state or federal level and shared taxes together make up more than half of the

\footnotetext{
${ }^{5}$ Initially, this quorum requirement did not exist. The participation rate in referenda was consistently lower than municipal elections (Scarrow, 1999). This observation may explain why the Constitutional Court of Bavaria ruled the lacking quorum requirement as unconstitutional so that the Bavarian state parliament had to adjust the Municipalities Law accordingly. The new quorum requirement took effect from 1 April 1999 onwards (Holtkamp et al. 2006). Like the signature requirement, the quorum requirement depends on the size of the municipality (Tables 5 summarizes the size dependent signature and quorum requirements).
} 
budgets. This limited autonomy on the revenue side is typical for the German model of cooperative federalism with its tradition of both extensive revenue sharing and farreaching equalization of differences in the jurisdictions' financial capacities.

\section{Data and preliminary analysis}

Our sample covers all Bavarian municipalities for the period between 1978 and 2011. The main fiscal variables of interest are total annual per capita expenditure and revenue in real terms.

Control variables include: demographic statistics, such as total population and share of working age population; and political variables, such as a dummy indicating years with a municipal election and share of different parties' seats at local councils ${ }^{6}$ Table 2 provides a complete summary statistics of all variables used in the analysis. Additionally, the last two columns of Table 5 present the variation in expenditures and the distribution of towns by population categories classified according to the thresholds in signature and quorum requirements.

Regarding data on direct democracy, this is the first study to exploit not the variation in direct democratic legislation as done before for US states or Swiss cantons but the actual usage of direct democratic tools. For this reason we employ a dataset on referenda collected by Universities of Wuppertal and Marburg in association with the NGO 'Mehr Demokratie' which promoted the establishment of municipal referenda in Bavaria and reports detailed data on all initiatives and referenda which took place in Bavaria since the 1995 reform. In particular, among others we have information on the date, location, topic, type, and result of these referenda. Overall there were 2437 initiatives, which resulted in 1303 referenda with exactly half of them being approved by a majority. The largest city and the capital of the State of Bavaria, Munich, had a total of 31 initiatives with an average rate of 2.6 initiatives per year during 1995-1999, when the direct democratic

\footnotetext{
${ }^{6}$ The fiscal data as well as the control variables are publicly available from the Bavarian statistical office.
} 
legislation was the most liberal, and dropping to 1.5 initiatives per year after the quorum requirements where introduced in 1999. The initiatives covered a wide range of topics with more than $80 \%$ of them constituting the following general areas with decreasing order of frequency: economic projects, transportation projects, public infrastructure, social and educational institutions, town planning. The direct democracy variables are summarized in the first three rows of Table 2 ,

Having defined the data we are now interested to see how the occurrence of these referenda affect local fiscal outcomes. As a first step, we estimate the following empirical model:

$$
y_{i t}=\alpha+R_{i t}+C_{i t}+\mu_{i}+\eta_{t}+\epsilon_{i t},
$$

where $y$ is the fiscal variable of interest, $R$ is a dummy variable indicating whether an initiative - alternatively: referendum (an initiative that gathered enough signatures and was implemented as a referendum) - has taken place in that year-town, $C$ is a set of controls , it correspond to municipalities and years accordingly, $\mu$ and $\eta$ are town and year fixed effects, and $\epsilon$ is the error term.

Tables 3 and 4 present the results for Equation 1 as the dependent variables having logarithms of annual real per capita expenditure and revenue respectively. In the first two columns of both tables we look at the simultaneous relation between fiscal variables and the two alternative definitions of direct democracy, while each subsequent set of two columns takes one additional backward lag of the direct democracy dummies.

Estimates from the first two columns of Tables 3 and 4 suggest that there is a negative correlation between the fiscal indicators of interest and the intensity of direct democratic activity regardless of their outcome. However, it is odd to expect an immediate effect of direct democracy on local fiscal policy, since the budgets are planned well in advance. In columns 3 to 8 of Tables 3 and 4 the independent variables of interest, the occurrence of initiatives and referenda, are lagged backwards up to the third year. We observe that in 
the first year following an initiative or referenda the sign is reversed to positive (columns: 3-4), but without significance at conventional levels. In the second and third years following an initiative or referenda, the tables point to a significantly positive relation between the intensity of direct democracy on one side and both expenditures and revenues on the other. As expected, the size of the coefficient is larger for the referenda dummy constituting an increase of around 2-3\% of annual expenditure and revenue on average (this is of considerable size, because as discussed earlier local government have true autonomy over around half of their budgets).

These first step results suggest neither a robust relation nor a causal interpretation between the instances of referenda, that is direct democracy in action, and local government expenditure and revenue. The reasons are the well-known endogeneity concerns for this selection on observables approach, for which this first approach is naive Angrist and Pischke, 2010). First, the estimates might be subject to reverse causality. That is, citizens might respond to changes in government economic policies by using the means that direct democracy offers them. In fact this could explain the reversing sign of the direct democracy indicators over time: first citizens react to low spending levels with more initiatives and referenda, which increase the government budget of the following years. Unobserved heterogeneity is another well-known issue here. Voter preferences, such as left ideology, are a good candidate.

\section{Identification}

The previous regressions might suffer from endogeneity problems. Therefore, we study in this section the effect of direct democracy on fiscal outcomes with a novel identification strategy which is increasingly being applied in fiscal federalism applications (see introduction). Since the signature and quorum requirements decrease discontinuously at the population thresholds indicated in Table 5, the extent to which local politicians are constrained by direct democratic institutions increases discontinuously at the these 
thresholds. Initializing direct legislation is harder in municipalities with population just below e. g. the 50,000 inhabitants threshold compared to municipalities just above the 50,000 threshold since significantly more (17\% more) signatures have to be collected. Similarly, quorum requirements for the approval of referenda are $(33 \%)$ higher below the same 50,000 threshold making direct democratic institutions even more liberal just above the population cutoffs.

The fact that direct democratic institutions change discontinuously at the thresholds implies that the causal effect of direct democracy can be established by means of a regression discontinuity design (Thistlewaite and Campbell, 1960; Imbens and Lemieux, 2008). The idea underlying this identification strategy is that there is some degree of randomness in whether municipalities have population sizes just above or just below a given threshold. Allocation of the treatment - more liberal direct democratic institutions - to municipalities should therefore be essentially random in close neighborhoods of a given threshold. This local randomization implies that municipalities with population sizes just above the threshold will have more liberal direct democratic institutions than those below even though both groups of municipalities should otherwise be on average identical.

A RDD can be implemented either non-parametrically or parametrically. The nonparametric approach relies on a comparison of municipalities with population sizes very close to the left and right of a respective threshold. However, as the number of observations close to a given threshold is limited, it is also customary to implement a parametric version of the RDD. The non-parametric RDD can be understood as a special case of the parametric RDD using data around very small windows of the thresholds. A general RDD model linking direct democratic legislation to fiscal outcomes can hence be formulated as:

$$
y_{i t}=\alpha+D_{i t}+f(n p)+D_{i t} * g(n p)+\eta_{t}+\epsilon_{i t} \text { if }|n p|<w_{b}
$$


where in our application $y$ is the fiscal variable of interest, $D$ is a dummy variable that is 1 if (normalized) municipal population size is above a given threshold, $f(n p)$ and $g(n p)$ are polynomials of (normalized) municipal population size, and $w_{b}$ is the bandwidth of the window. Following Egger and Köthenbürger (2010), we analyze all thresholds simultaneously by centering the data around a single 0 threshold and hence normalize municipal population size accordingly $]^{7}$ Note that, when calculating the treatment dummy, the population numbers are taken from the previous year of the last election, since by Bavarian law population figures to be adopted in legal affairs of municipalities are those at six months prior to the last municipal elections.

The idea underlying this specification is that a flexible polynomial of normalized population size controls for all continuous effects of municipal population on fiscal policy, while the normalized threshold dummy captures the effect of the discontinuous decrease in the signature and quorum requirements. Note that the slope of the polynomials of population size is allowed to differ to the left and right of the thresholds. That is, population size is allowed to affect the relevant fiscal variable differently on either side of the threshold (i.e. $f(n p)$ unequal $g(n p))$.

One important assumption underlying the specification in Equation 2 is that conditional on the polynomials of normalized population size, municipalities are identical in all respect except for the signature and quorum requirements. The assumption that a parametric function of population size can control for all municipal characteristics becomes ever more questionable as municipalities with population sizes farther away from the thresholds are included. On the other hand, using only observations close to the threshold results in significant sampling variability. Thus, choosing windows involves a trade-off between reducing bias and increasing efficiency. Limiting the sample to observa-

${ }^{7}$ More formally, the RDD dummy is defined as:

$$
D_{i t}= \begin{cases}1, \text { if } & \ln \left(N_{i t} / N_{d}\right)>0 \\ 0, \text { if } & \ln \left(N_{i t} / N_{d}\right) \leq 0\end{cases}
$$

where $N_{i t}$ is the population size and $N_{d}$ are the population thresholds specified by columns 2 (for signature requirements) and 3 (for quorum requirements) of Table 5 , which define the normalized population: $n p=\ln \left(N_{i t} / N_{d}\right)$. 
tions very close to the thresholds reduces bias as "treatment" and "control" municipalities are identical in expectation. However, as the window sizes and hence the number of observations increases the estimates become susceptible to outliers and other sources of sampling variability.

Equation 2 is therefore estimated along different windows $w$ of normalized population size (for summary statistics on the bandwidths see the bottom six rows of Table 2). 8

Several additional assumptions must hold for the RDD as specified in Equation 2 to produce valid estimates. First, only the direct democratic institutions should change at the thresholds. Second, population size must be exogenous and manipulation reliably excludable. The first assumption is definitely violated in our institutional context. Egger and Köthenbürger (2010) write that the size of the local council changes discontinuously at some of the same thresholds and find that it positively affects government spending. In a critique to Egger and Köthenbürger (2010), Ade and Freier (2011) show that in addition to council size, there exist a number of additional institutions that change at these thresholds. In terms of budgetary rules, towns that have populations exceeding 30,000 and 50,000 may apply for the status of a larger city ("Große Kreisstadt") and county free city ("Kreisfreie Stadt") accordingly, which may imply additional, although limited, expenditure tasks and revenue sources. Second, the wages of elected civil servants change at some of the same thresholds as well. Finally, population thresholds are also relevant for the horizontal fiscal equalization system, which allocates discontinuously more benefits to towns that are larger than 50,000 in size..$^{9}$

\footnotetext{
${ }^{8}$ Six different bandwidth sizes are defined as:

$$
w_{b}=\left\{\begin{array}{cl}
1 \%, \text { if } & -0.01<\ln \left(N_{i t} / N_{d}\right)<+0.01 \\
2 \%, \text { if } & -0.02<\ln \left(N_{i t} / N_{d}\right)<+0.02 \\
5 \%, \text { if } & -0.05<\ln \left(N_{i t} / N_{d}\right)<+0.05 \\
10 \%, \text { if } & -0.1<\ln \left(N_{i t} / N_{d}\right)<+0.1 \\
15 \%, \text { if } & -0.15<\ln \left(N_{i t} / N_{d}\right)<+0.15 \\
30 \%, \text { if } & -0.3<\ln \left(N_{i t} / N_{d}\right)<+0.3
\end{array}\right.
$$
}

${ }^{9}$ There are a few additional size-dependent rules of more minor importance or that apply to towns
smaller than 10,000, which will not affect our results. For a detailed discussion see Ade and Freier (2011). 
Therefore, a simple RDD as specified in Equation 2 is unlikely to reveal the isolated causal effect of direct democracy but rather a confounded impact of several of the above factors varying with population size.

We address this problem by using the fact that direct democracy was only introduced in 1995 in Bavaria whereas the above-mentioned population thresholds existed long before and remained constant in the period under consideration. There is hence a pre- and posttreatment period. We exploit this over-time variation in direct democracy by studying whether the effect of the thresholds on spending differs between the pre- and post-reform periods.

Initially, we exploit the temporal dimension of our data by estimating Equation 2 in the period before and after the introduction of direct democracy. A comparison of the estimated treatment effect from these two subsamples will give a first impression of the effect of direct democracy. This approach to identify the causal effect has the advantage of being very simple and transparent. In a second step, however, we exploit the over-time variation in a more formal framework by combining the RDD with a difference-in-difference analysis. The idea is to explore how the effect of the discontinuity on expenditure changes once direct democratic institutions are introduced. A formal treatment of this difference-indiscontinuity (DiD) approach and an application using Italian municipalities is available in Grembi et al. (2012). In our setting, the DiD model can be specified as:

$$
y_{i t}=\alpha+D_{i t} * T_{i}+D_{i t}+T_{i}+f(n p)+D_{i t} * g(n p)+\eta_{t}+\epsilon_{i t} \text { if }|n p|<w_{b},
$$

where $T$ is a dummy variable that equals 1 starting from the year 1995 on (the introduction of direct democracy) - alternatively: T equals 1 starting 1999 (the introduction of quorum requirements) - and else 0. All other variables are defined as in Equation 2.

An important requirement for a valid RDD is that municipalities should not have been able to selectively sort around the thresholds (Lee, 2008; Ade and Freier, 2011). Some municipalities might have had the ability to precisely manipulate their population sizes 
such that they were either just below or just above a relevant threshold. For example, municipalities governed by a right-wing mayor might have been adverse to direct democracy and thus made sure to remain just below the relevant population threshold whereas municipalities with left-wing governments might have been eager to overcome the next higher threshold. In such cases of selective manipulation, the estimated effect of direct democratic legislation on fiscal policy would be contaminated by the effect of ideology. While ideology could be observed and explicitly controlled for in the parametric RDD, there might be unobservable variables that lead to the same problems.

Manipulation is difficult but possible in principle. Population sizes are calculated by the state statistical office, which is a state-level institution outside of the control of municipal officials. While the statistical office relies on data provided by the municipalities to update annual population figures, outright and persistent misreporting will evoke suspicion. There might be some leeway through particular municipal (dis)incentives set for new residents to register or moving residents to unregister. Hence, the accurateness and timeliness of population data might differ across municipalities and be biased according to the particular municipal interests.

However serious this problem is, violation of the standard no-manipulation assumption is less severe in our DiD than in other settings as we rely on differences in the effect of the threshold between the pre- and post-treatment period. As long as those municipal characteristics that allow municipalities to manipulate population sizes are time-constant, we will be able to consistently estimate the treatment effect even if there is manipulation.

In order to explore whether there was selective manipulation during the sample period, one simple approach is to compare the densities of municipal population sizes at the thresholds. Spikes around the thresholds would point toward selective manipulation. Histograms of municipal population sizes using the default bin size together with their Kernel plots are presented in Figure 4 with 1, 2, 5, 10, 15 and $30 \%$ bandwidths around 
the normalized threshold. Although some discontinuity is observed at particularly larger bandwidths, the density plots do not provide strong evidence of selective sorting, 10

More formal evidence can be obtained through McCrary plots (McCrary, 2008). We provide three McCracy plots for the normalized thresholds in Figure 5 using the default bandwidth and bin sizes. The plot in Subfigure (a) is based on the raw data. It suggests a positive discontinuity at the threshold. At first sight, this would indicate that some municipalities were able to selectively sort around the thresholds. However, Bavaria as a whole witnessed during the sample period a continuous increase in population size. It is possible that because of the state-wide increase in population, more municipalities have crossed the relevant thresholds from below than from above. While this should not matter for very close bandwidths around the normalized threshold, not accounting for state-level trends might lead to wrong conclusions once observations that are farther away from the threshold are used. Therefore, we present in Subfigure (b) a McCrary plot based on time-demeaned data, i. e. where the population figures have been demeaned for year dummies. In this subfigure, there is no strong evidence for a discontinuity.

Another response to concerns regarding selective sorting is that we ultimately rely on DiD regressions for identification, i. e. a comparison of the effects of the threshold prior and after the direct democracy treatment. As argued above, therefore, our identification strategy based on population thresholds should be valid even if there is selective sorting as long as the factors that allow municipalities to sort around the thresholds are time-constant. To validate that any such factors, if they exist, are likely time-constant, we report in Subfigure (c) of Figure 5 a McCrary plot with data that is demeaned for municipality fixed effects. There is no strong evidence for a discontinuity in this subfigure.

\footnotetext{
${ }^{10}$ Ade and Freier (2011) perform similiar tests, however their inference is based only on the $15 \%$ bandwidth.
} 


\section{Results}

\subsection{Graphical evidence}

We begin with the graphical evaluation of the treatment effect of direct democracy. Figure 6 presents a local polynomial smooth of logarithmized per capita expenditure and revenue at the normalized threshold. We present results for the whole sample (1978-2011), and additionally for a restricted pre-reform (1978-1994) and post-reform sample (1995-2011). To account for outliers, the plots are constructed based on bin averages. We use a bin width of 0.01 for normalized population size and average the logarithmized expenditures and revenues per capita accordingly ${ }^{11}$ Since population size is normalized, the treatment sets in at 0 in the plots ${ }^{12}$

The evidence for the full sample, reported in Subfigures (a) and (b) of Figure6, suggests that there is a positive discontinuity at the population thresholds, that is municipalities to the right of the threshold spend more and have higher revenues than those to the left. However, as mentioned previously the thresholds relevant for direct democratic legislation are important for council size as well (and as discussed below for a number of additional factors). It is difficult to tell whether the discontinuity in expenditures and revenues is due to the improved ability to initiate direct democratic legislation or due to council size or other factors. But since there is a pre- and a post-treatment period, we can split the sample and explore the magnitude of the discontinuity in the two periods in order to establish the effect of direct legislation. Subfigures (c) and (d) report the discontinuity plots for the pre-treatment period. In the pre-1995 period, there is no evidence for a positive discontinuity. In fact, there is even a negative discontinuity, albeit a very small one. However, in the plots for the post-treatment period, reported in Subfigures (e) and (f), there is a positive discontinuity that is of the same magnitude as in the full sample. The subfigures based on the split sample suggests that the positive discontinuity found for

\footnotetext{
${ }^{11}$ Plots with other bin widths are very similar.

${ }^{12}$ We restrict the plots to a bandwidth of 0.4 to the left and right of the normalized threshold. Since there are very few observations far away from the threshold, individual observations have a very strong effect on the scaling of the plot if a larger bandwidth is used.
} 
the full sample was indeed due to direct democratic legislation rather than other factors. In the next section, we explore whether this conclusion can be validated by a more formal RDD analysis.

\subsection{Regression discontinuity results}

Tables 6 and 7 present the results from estimating Equation 2 on local expenditure and revenue respectively, with the bandwidth size varying from 1 to $30 \%$ (columns) and up to the fourth polynomial (rows). The upper panels A present results with a sample that covers both pre- and post-reform periods and thus lasts from 1978-2011. The estimates are significant while the sign of the coefficient is positive for both of the fiscal indicators.

Next, as in the case of the graphical analysis, we split the sample into pre- and a postreform periods. When we restrict the estimations to the pre-reform era, we should expect no effect at the threshold as there was no direct democratic legislation in this period. However, as discussed above there are institutional factors other than direct democracy that change at the same thresholds as the features of direct legislation but which were in place before direct democracy was introduced. These other treatments are reflected in our analysis by unstable results in the pre-reform sample (Panels B of Tables 6 and 7). For small bandwidths we observe negative and significant discontinuities, as it was the case in the graphical analysis above. These effects turn out to be insignificant with increasing bandwidth size and reverse to positive results for the larger bandwidths.

The results become stable when we restrict the sample to the post-reform period (Panels $\mathrm{C}$ of Tables 6 and 7 . In both expenditure and revenue equations we observe a significantly positive effect of the treatment dummy robust to all bandwidths and polynomials.

As argued above, with the existence of other discontinuities, a pure RDD, albeit its strong results, may become unreliable for identification. Thus, in the next section we aim at separating the effect of direct democratic institutions from this unnecessary noise in a more formal way. 


\subsection{Difference-in-discontinuity results}

Next we present the results obtained by the DiD estimator. Tables 8 and 9 present the results from estimating Equation 3 for the 1995 direct democracy reform as the dependent variable taking, respectively, per capita expenditure and revenue as before. Unlike the RDD case above, here we are able to estimate the total effect of the variation in signature and quorum requirements of initiating referenda net of the other effects, such as the council size or the fiscal equalization. This is possible because although the other discontinuities vary at some of the same thresholds as the signature and quorum requirements, they are constant over time, thus by differencing the pre- and post-reform periods we can control for these effects.

The results indicate a significant and robust impact of direct democracy on public spending amounting to an average increase of roughly 150 Euros in annual per capita municipal expenditure (or around $10 \%$ of a median town, Table 8). A very similar pattern emerges for government revenue (Table 9).

\subsection{Further robustness checks}

Another way to address the concerns regarding the validity of the RDD assumptions is to look at the effects of each of the thresholds separately. One issue is the question of selective sorting around the thresholds. As discussed above, local politicians can benefit from increased size through, for example, higher wages or bigger budgetary provisions. On the other hand and unlike say the program evaluation literature where scores are relatively easy to manipulate, our identification is based on more or less precise population count. Nevertheless, the population histograms in Figure 4 do not show a perfectly equal distribution around the thresholds. The second concern is the presence of other simultaneous co-treatments at some of the same thresholds. 
We believe that the DiD logic entire rules out the two latter concerns ${ }^{13}$ but for the more skeptical reader in this section we additionally look at the thresholds separately. First regarding the manipulation argument, this approach is motivated by the fact that population sorting may be stronger at some thresholds and weker in others. In case of the second argument, the other institutions do not change at all of our thresholds. For example, the important discontinuity in the fiscal equalization system applies to the 10, 50 and 100 thousand thresholds and not to the 20 and 30 thousand thresholds (Ade and Freier, 2011).

Table 10 presents a replication of the previous DiD estimates at some of the population thresholds separately, rather than pooling all thresholds together as before. We choose the 10, 20 and 30 thousand thresholds, because for higher thresholds at least for the $5 \%$ bandwidth size the number of observations is less than a hundred. The evidence generally proves the robustness of our findings to different thresholds and for alternative fiscal variables.

\subsection{Impact of signature and quorum requirements}

Our identification strategy has benefited from exploiting the exogenous variation in direct democratic institutions, which relies on the crucial assumption that higher (lower) signature and quorum requirements reduce (increase) the intensity of direct democratic control. But does such a phenomenon really emerge in practice?

As described above, voters in all German Länder have the constitutional right to petition for popular initiatives, but the degree of openness of direct democratic instruments is exposed to a considerable variance both across -states and -municipalities. In an analysis for German Länder, Eder et al. (2009) empirically show that the number of signature requirements and the (inverse of) time granted to collect them is strongly negatively correlated with the actual number of popular initiatives.

\footnotetext{
${ }^{13}$ An additional safeguard against the suspicion of Ade and Freier $(2011)$ on using population thresholds for identification is the fact that our results are robust to bandwidths as close to the threshold as $1 \%$, while their evidence is based only on a much larger $15 \%$ bandwidth.
} 
We test this proposition for Bavarian towns by running a logarithmic variant of the RDD regression specified in Equation 2. The dependent variable $y_{i t}$ is now a binary variable indicating whether an initiative or alternatively a referendum (an initiative that is implemented as referenda) has taken place in that year-town. For the former we expect a positive sign, because citizens of towns below the (normalized) thresholds are exposed to dis-proportionally high signature and quorum requirements, thus are less likely to start a petition. The effect is expected to be stronger for the referendum dummy, since this is an indicator for actually implemented referenda which have to pass the signature requirements of the initiative process.

The results are presented in Table 11. The coefficients are positive, and significant in some cases. One reason for not reaching the conventional confidence intervals across all specifications is the low number of observations around the thresholds. In columns 4-6, for example, within the 5, 10 and 15\% bandwidths we observe respectively 59, 127 and 176 referenda. Nevertheless, the positive and occasionally significant coefficient presents additional evidence on the significance of the differences in direct democratic institutions at the population thresholds.

\section{Conclusion}

This paper is the first systematic study to extend the discussion on the link between direct democratic institutions and local-level public finances to the case of German municipalities. In the second half of 1990's under the pressure of grass roots organizations the German state of Bavaria has gone through a series of political reforms that have significantly liberalized direct democratic institutions at the local level. We use the variation stemming from this legal intervention and apply a quasi-experimental design to study the causal effects of the ease of initiating and implementing popular referenda in a large sample of 2099 Bavarian municipalities over the period from 1978 to 2011. 
We exploit the fact that by the Bavarian law citizens' signatures needed to initiate referenda, as well as the quorum requirements for referenda to be approved, vary discontinuously at some population thresholds. Since the sizes of the municipalities are approximately randomized at the exogenously assigned population thresholds, we can use a regression discontinuity design to study the effect of the variation of direct democratic legislation on otherwise identical municipal fiscal outcomes. The validity of these estimates are cross-checked by applying a DiD approach, which measures the causal effect of the direct democratic reform through comparing the discontinuities between the pre- and post-reform periods. Thus, we cope with RDD difficulties related to multiple function thresholds and manipulations of population data which have recently attracted attention (Ade and Freier, 2011).

We are able to empirically show that the size-dependent signature and quorum requirements are a strong determinant for the degree of openness of direct democratic institutions. Consequently, our results indicate that unlike most studies on Switzerland, direct democracy had a significantly positive and robust effect on both public expenditures and revenues for the given institutional setting. The combined effect of the variation in signature and quorum requirements amounts to an average increase of around $10 \%$ in annual per capita expenditure and revenue for a median town.

At a more theoretical level, our findings appear to be consistent with the median voter world where the voters are fiscally less conservative than their elected representatives. This difference between the voters' and their representatives' preferences is likely to be very diverse across countries, which would be one explanation for the different results in the studies for Switzerland and the US vs. our study.

However, voters' preferences are not the only and not necessarily the right, explanation to the link between direct democracy and public finances. The specific features of the German federal setting might be the key. German federalism is often considered to have substantive common pool disincentives. This problem also affects municipal budgets in Bavaria in several regards. First, Bavarian municipalities depend heavily on shared 
taxes and grants received from the state of Bavaria. Second, Bavaria itself is serving as a long-time net contributor to the horizontal fiscal equalization system among German states. Bavarian net-payer status is subject to a constant public debate. Significant direct democracy only exists at the lowest federal level. Bavarian citizens nowadays have significant direct democracy rights on the local-level, but initiating referenda on a state level remains very hard and virtually impossible on the federal level. Thus, through exploiting their direct voice at the bottom level, Bavarian voters have an incentive to overspend from the common pool on which other jurisdictions and governmental levels, in their view, have superfluous access. 
Figures and Tables 
Figure 1: Total number of initiatives in German states, 1956-2013

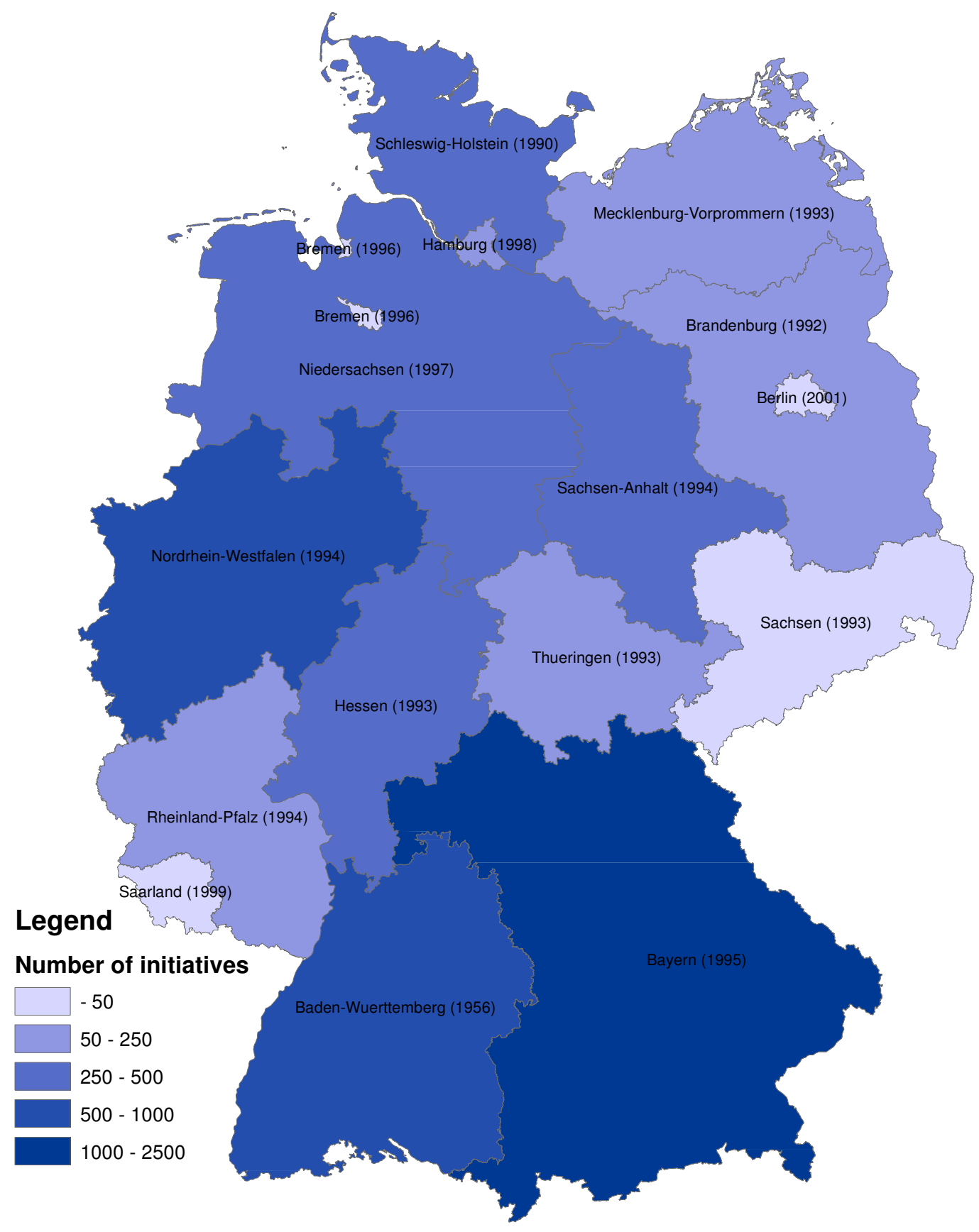

Notes: Total number of local-level initiatives per Land starting from 1956 (the year when two German Länder for the first time adopted initiative legislation) to March, 2013. The year of first initiative (usually coincides with the year of adopting initiative legislation) is in parentheses. 
Figure 2: Total number of initiatives in Bavarian towns, 1995-2011

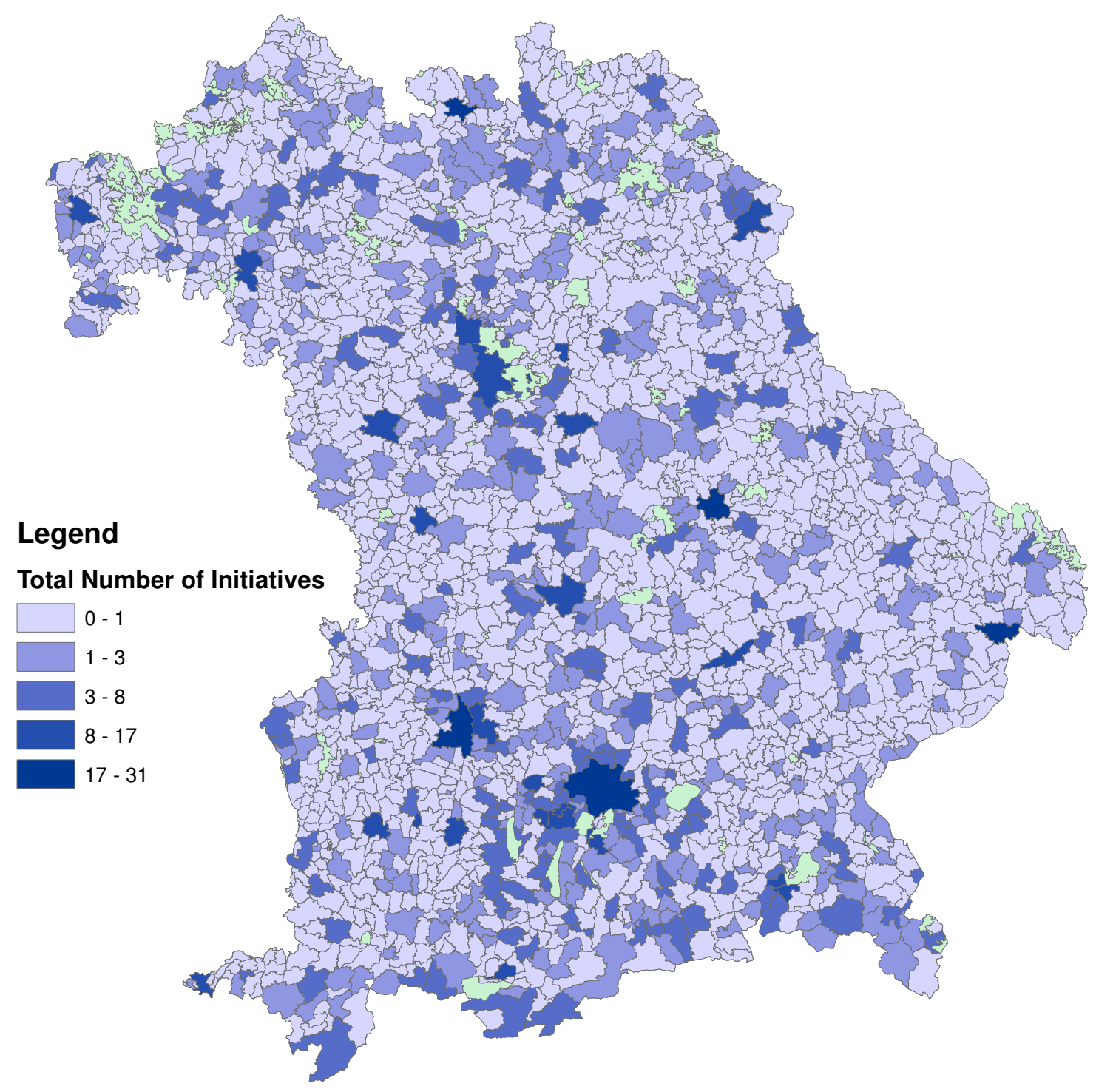

Notes: Total number of local-level intiatives per Bavarian municipalities, starting from 1995 (the year when initiative legislation was adopted) to 2011. 
Figure 3: Annual number of initiatives and referenda in Bavarian towns, 1995-2011

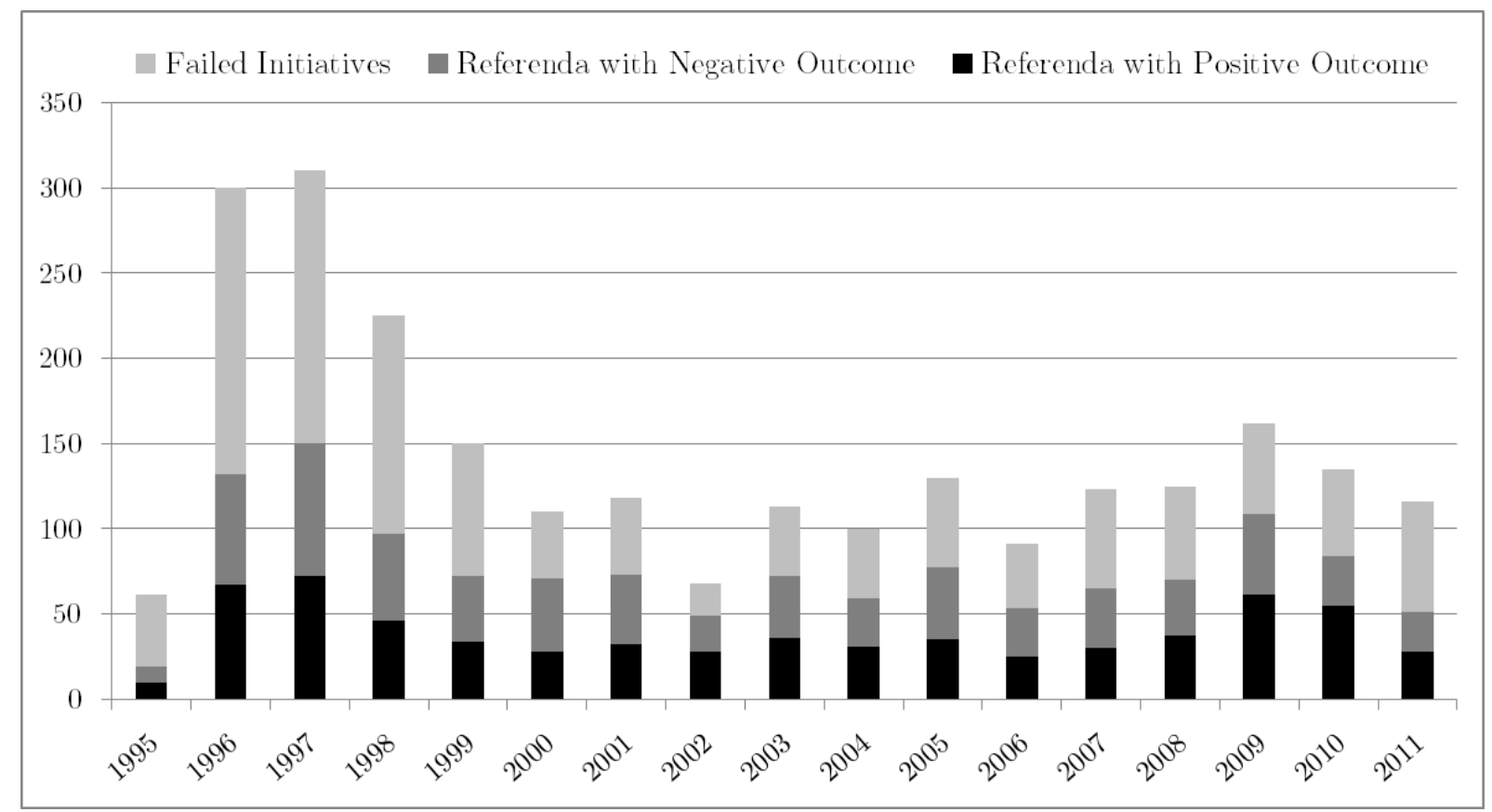

Notes: Annual total local-level intiatives and referenda in all Bavarian municipalities. The initiative legislation was adopted in October 1995 as a result of a state-wide referendum and was revised in April 1999, when additional quorum requirements were introduced. 
Figure 4: Histogram of log pre-election-year population around the normalized threshold with Kernel density plots

(a) BANDWIDTH: $1 \%$

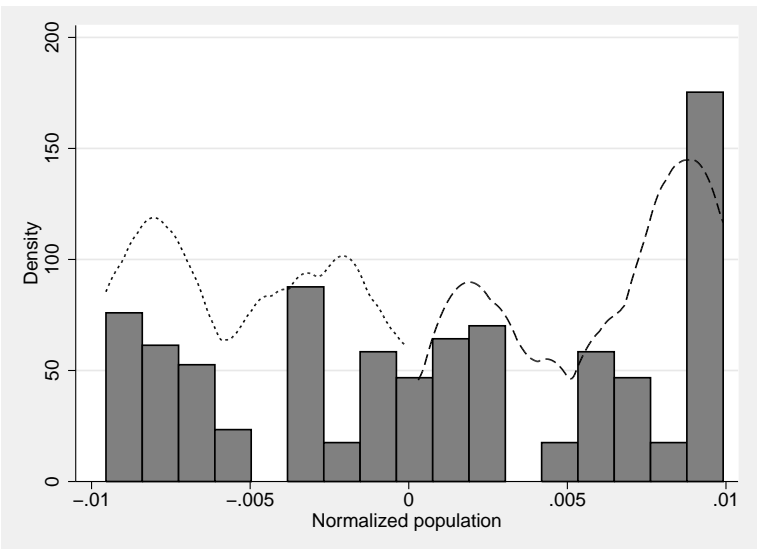

(c) BANDWIDTH: $5 \%$

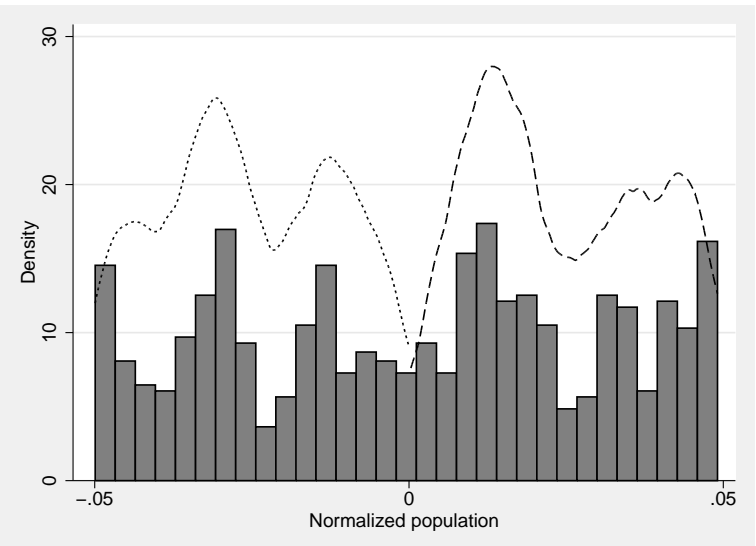

(e) BANDWIDTH: $15 \%$

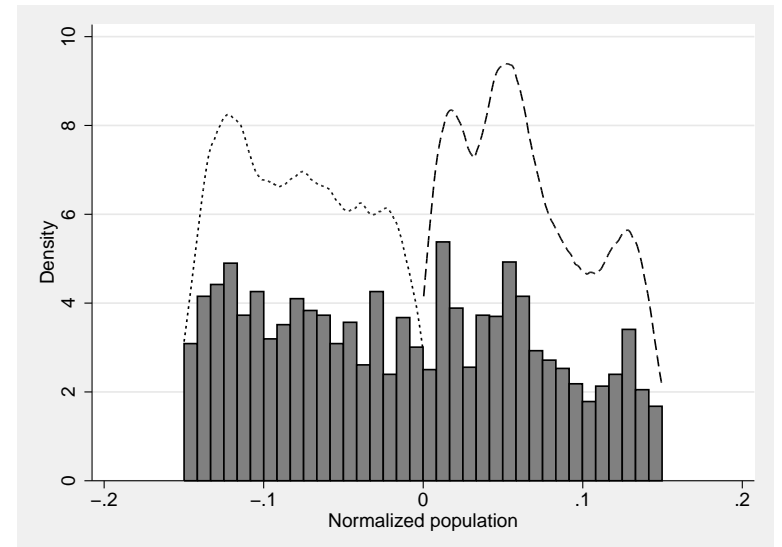

(b) BANDWIDTH: $2 \%$

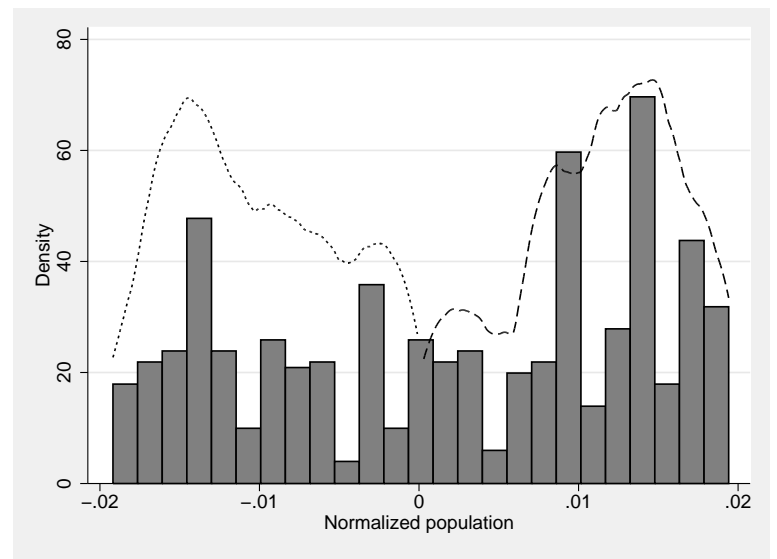

(d) BANDWIDTH: $10 \%$

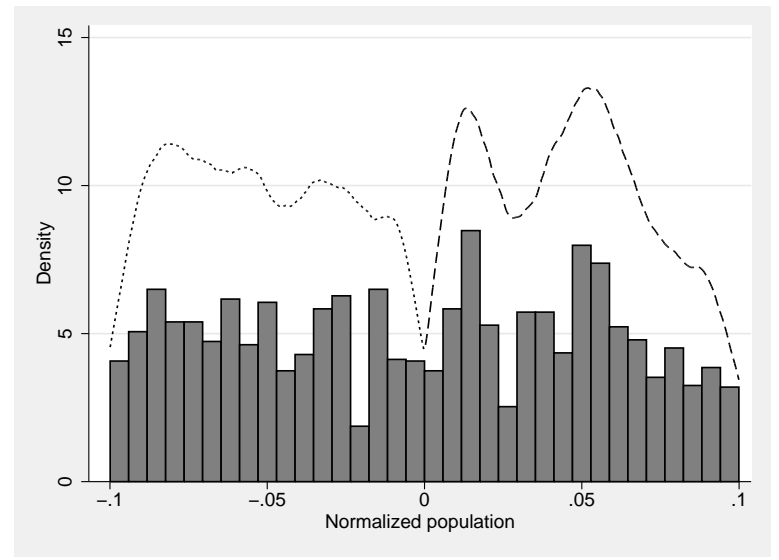

(f) BANDWIDTH: $30 \%$

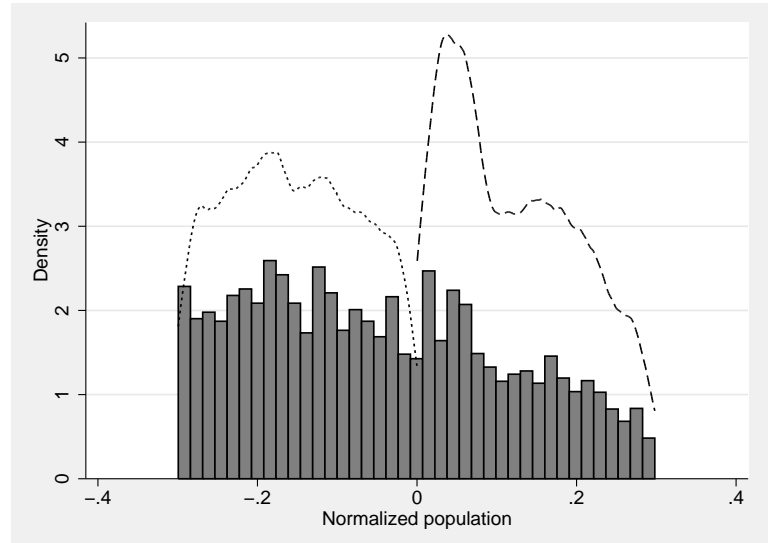


Figure 5: McCracy plots for the normalized thresholds

(a) NON-DEMEANED DATA

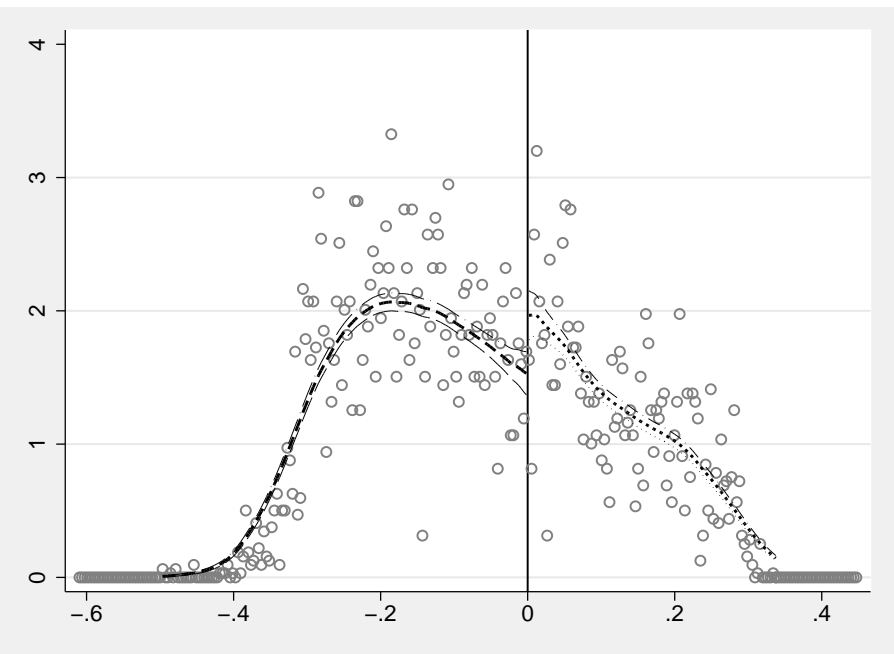

(b) TIME-DEMEANED DATA

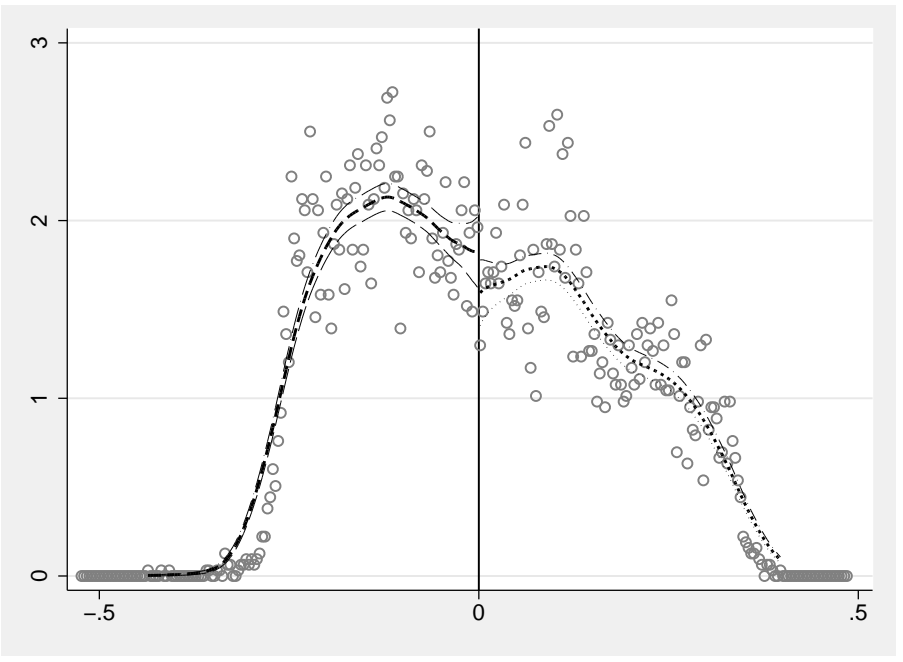

(c) CROSS-SECTION DEMEANED DATA

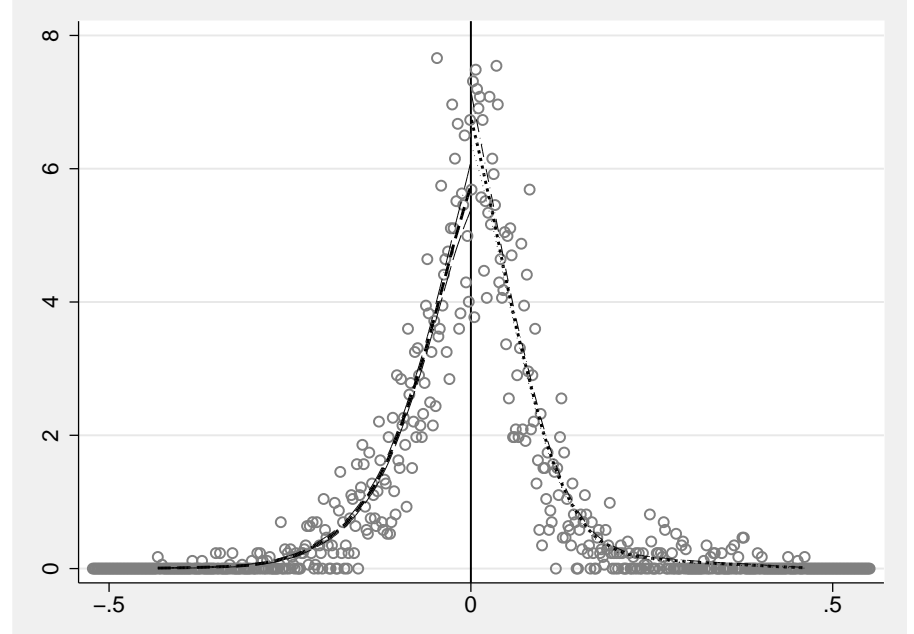


Figure 6: Local polynomial smooth of municipal expenditure (left) and revenue (right) around the normalized threshold

(a) Full sample: Expenditure

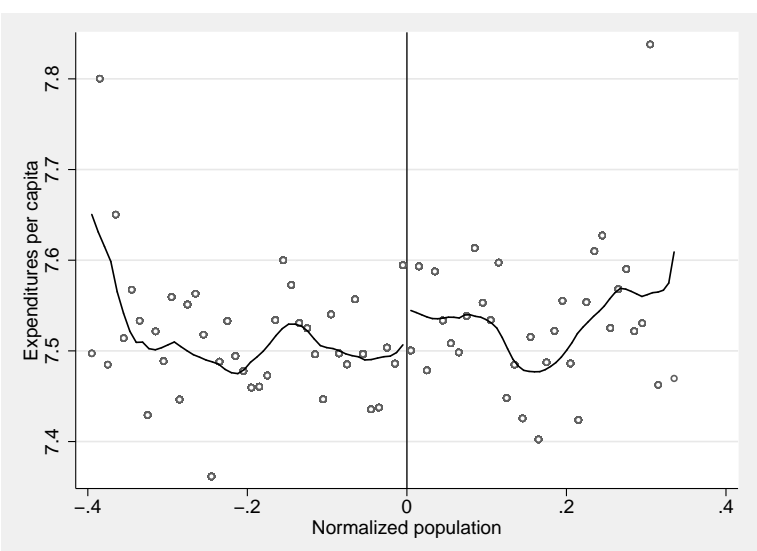

(c) Pre-1995: Expenditure

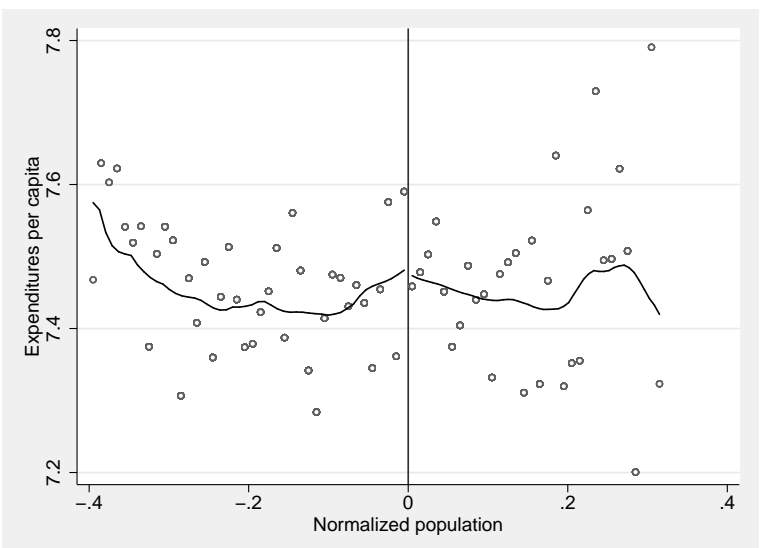

(e) Post-1995: Expenditure

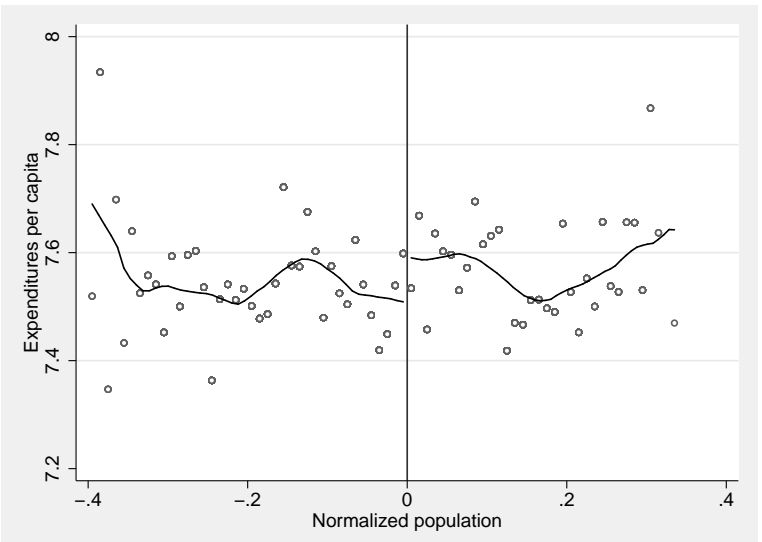

(b) Full sample: Revenue

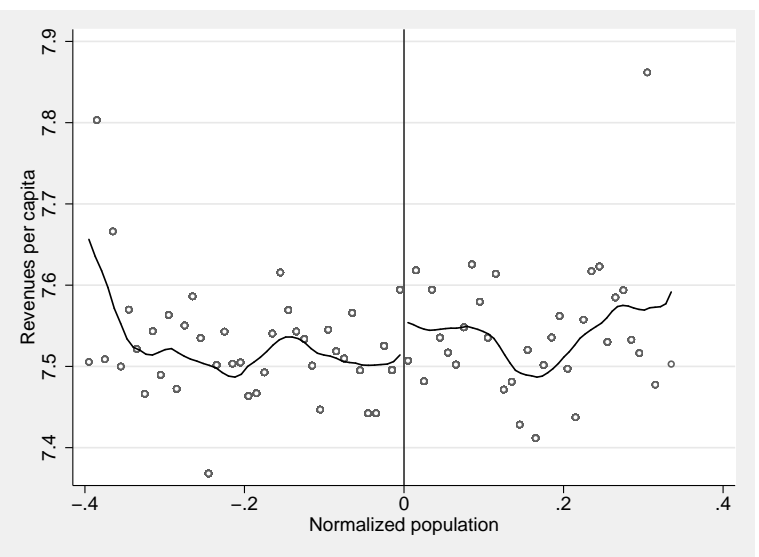

(d) Pre-1995: Revenue

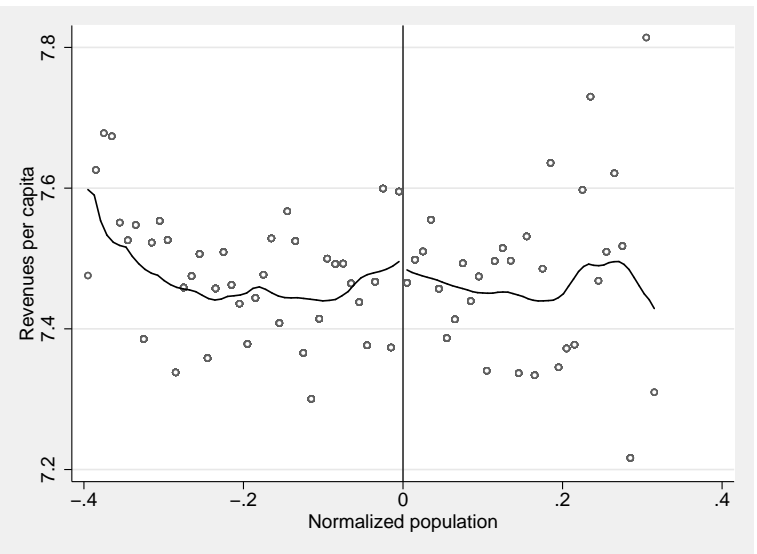

(f) Post-1995: Revenue

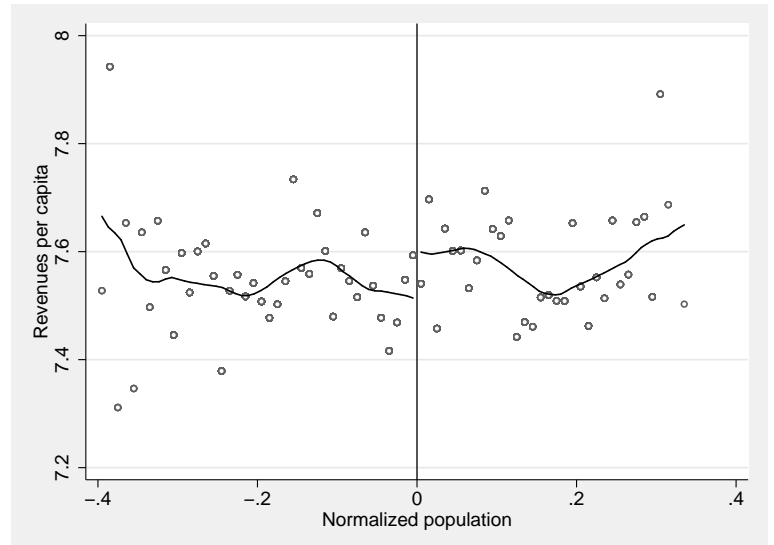


Table 1: Revenue structure of Bavarian municipalities in 2012

\begin{tabular}{lcc}
\hline \hline Revenue Source & Amount, mln. EUR & Share, $\%$ \\
\hline Autonomous taxes & 7,830 & $26.4 \%$ \\
Shared taxes & 6,187 & $20.8 \%$ \\
Grants (state, federal) & 9,758 & $32.9 \%$ \\
Fees & 3,544 & $11.9 \%$ \\
Other (e.g. property income) & 2,354 & $7.9 \%$ \\
\hline Total & 29,672 & $100.0 \%$ \\
\hline \hline
\end{tabular}

Source: Own calculations based on Bayerisches Landesamt für Statistik und Datenverarbeitung (2013). 


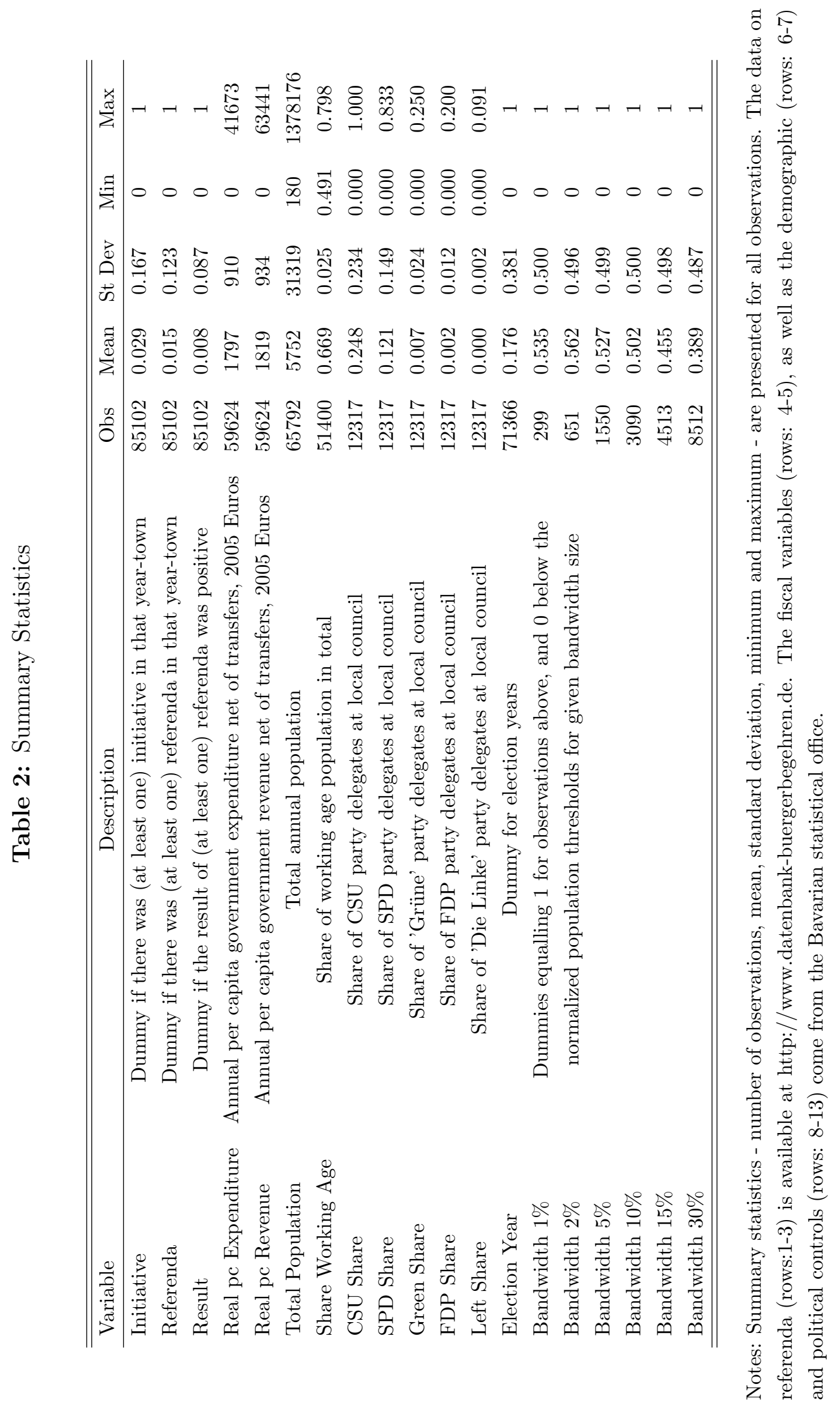




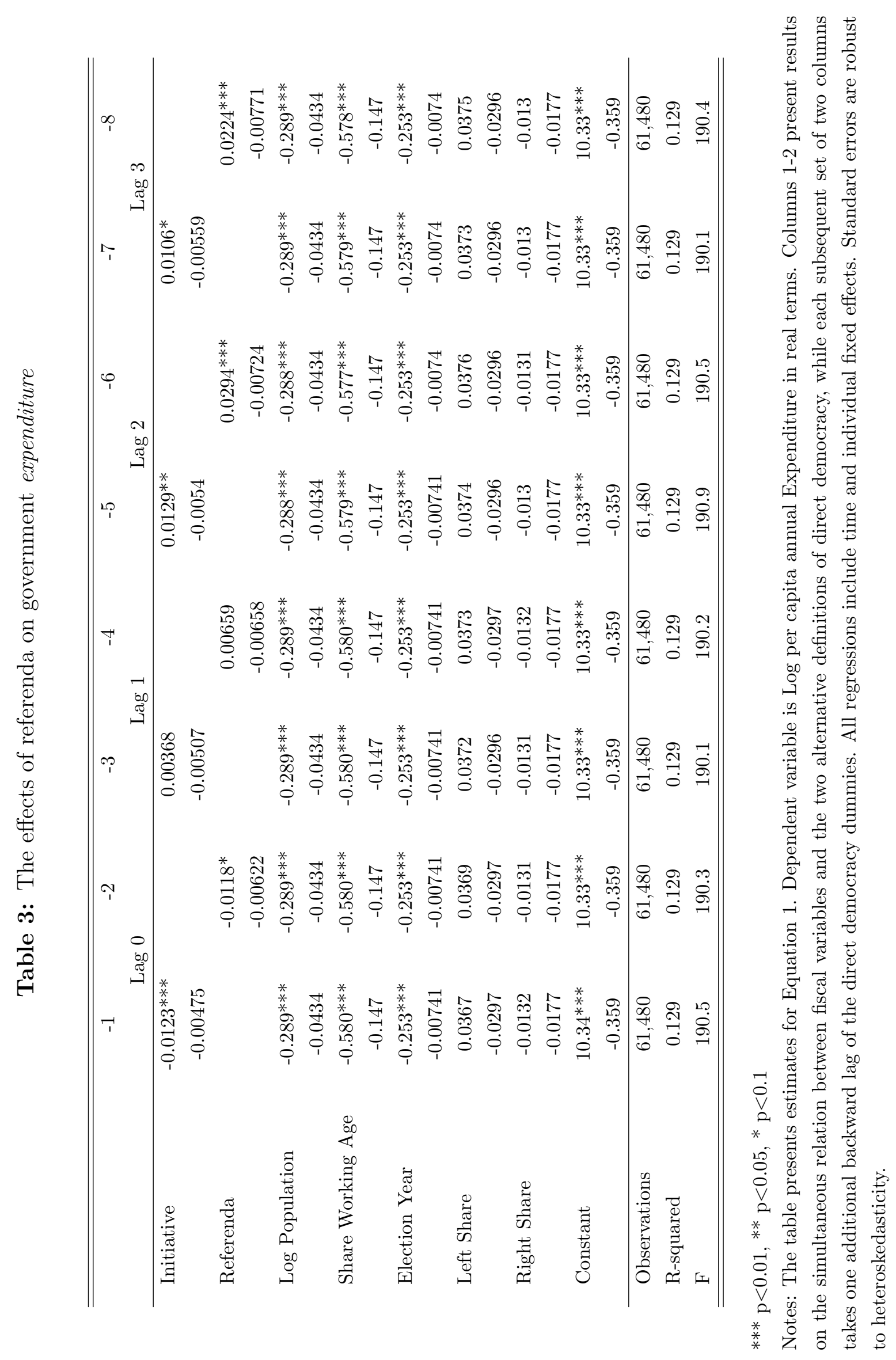




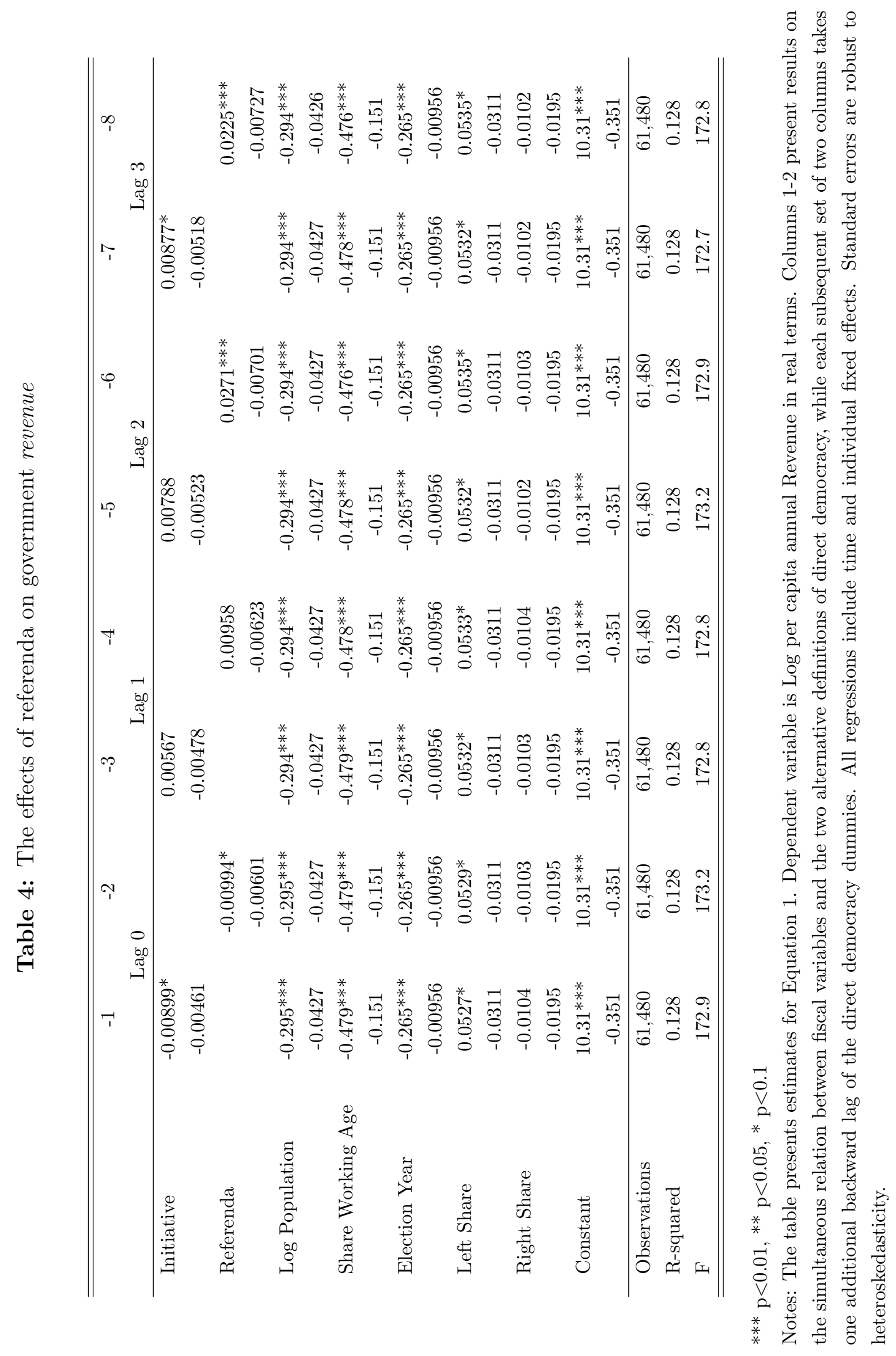


Table 5: Signature and quorum requirements by population categories

\begin{tabular}{lcccccc}
\hline \hline & $\begin{array}{c}\text { Categories by } \\
\text { Population Size }\end{array}$ & $\begin{array}{c}\text { Signature Requirement } \\
(1995)\end{array}$ & $\begin{array}{c}\text { Quorum Requirement } \\
\text { \% of total population }\end{array}$ & $\begin{array}{c}\text { Median pc } \\
\text { \% of eligible voters }\end{array}$ & $\begin{array}{c}\text { Obs. } \\
\text { 2xpenditure }\end{array}$ \\
& & 1005 Euros & \\
\hline 0 & $<=$ Pop Size $<$ & 10000 & $9 \%$ & $20 \%$ & 1494 & 59329 \\
10000 & $<=$ Pop Size $<$ & 20000 & $8 \%$ & $20 \%$ & 1601 & 4567 \\
20000 & $<=$ Pop Size $<$ & 30000 & $8 \%$ & $20 \%$ & 1580 & 841 \\
30000 & $<=$ Pop Size $<$ & 50000 & $7 \%$ & $20 \%$ & 2035 & 504 \\
50000 & $<=$ Pop Size $<$ & 100000 & $6 \%$ & $15 \%$ & 2399 & 315 \\
100000 & $<=$ Pop Size $<$ & 500000 & $5 \%$ & $10 \%$ & 2486 & 197 \\
500000 & $<$ Pop Size & $3 \%$ & $10 \%$ & 3259 & 39 \\
\hline \hline
\end{tabular}

Source: Gemeindeordnung für den Freistaat Bayern (version: 24.07.2012). 
Table 6: RDD: the effect of population thresholds on government expenditure

\begin{tabular}{|c|c|c|c|c|c|c|}
\hline Bandwidth: & $+/-1 \%$ & $+/-2 \%$ & $+/-5 \%$ & $+/-10 \%$ & $+/-15 \%$ & $+/-30 \%$ \\
\hline \multicolumn{7}{|c|}{ Panel A: 1978-2011 } \\
\hline 1st Polynomial & 0.00502 & $0.0809^{* * *}$ & $0.114^{* * *}$ & $0.102^{* * *}$ & $0.113^{* * *}$ & $0.0462^{* * *}$ \\
\hline 2nd Polynomial & 0.00984 & $0.0989 * * *$ & $0.131^{* * *}$ & $0.124^{* * *}$ & $0.127^{* * *}$ & $0.0861^{* * *}$ \\
\hline 3rd Polynomial & 0.0129 & $0.140^{* * *}$ & $0.144^{* * *}$ & $0.124^{* * *}$ & $0.126^{* * *}$ & $0.0894^{* * *}$ \\
\hline 4th Polynomial & 0.0326 & $0.148^{* * *}$ & $0.164^{* * *}$ & $0.121^{* * *}$ & $0.123^{* * *}$ & $0.106^{* * *}$ \\
\hline Observations & 269 & 588 & 1409 & 2823 & 4120 & 7795 \\
\hline \multicolumn{7}{|c|}{ Panel B: 1978-1994 } \\
\hline 1st Polynomial & $-0.180^{* * *}$ & -0.0232 & $0.0480^{*}$ & $0.0760 * * *$ & $0.0867^{* * *}$ & $0.0297^{*}$ \\
\hline 2nd Polynomial & $-0.195^{* * *}$ & -0.028 & $0.0521^{*}$ & $0.0870^{* * *}$ & $0.0983^{* * *}$ & $0.0573^{* * *}$ \\
\hline 3rd Polynomial & $-0.181^{* *}$ & 0.0155 & $0.0665^{* *}$ & $0.0913^{* * *}$ & $0.0821^{* * *}$ & $0.0653^{* * *}$ \\
\hline 4th Polynomial & $-0.184^{* *}$ & 0.0778 & $0.0687^{*}$ & $0.0838^{* * *}$ & $0.0792^{* * *}$ & $0.110^{* * *}$ \\
\hline Observations & 123 & 236 & 615 & 1140 & 1641 & 2868 \\
\hline \multicolumn{7}{|c|}{ Panel C: 1995-2011 } \\
\hline 1st Polynomial & 0.0878 & $0.130^{* * *}$ & $0.162^{* * *}$ & $0.122^{* * *}$ & $0.141^{* * *}$ & $0.0562^{* * *}$ \\
\hline 2nd Polynomial & 0.0796 & $0.168^{* * *}$ & $0.204^{* * *}$ & $0.146^{* * *}$ & $0.149^{* * *}$ & $0.108^{* * *}$ \\
\hline 3rd Polynomial & $0.112^{*}$ & $0.194^{* * *}$ & $0.204^{* * *}$ & $0.152^{* * *}$ & $0.164^{* * *}$ & $0.102^{* * *}$ \\
\hline 4th Polynomial & $0.117^{*}$ & $0.216^{* * *}$ & $0.231^{* * *}$ & $0.158^{* * *}$ & $0.161^{* * *}$ & $0.106^{* * *}$ \\
\hline Observations & 146 & 352 & 794 & 1683 & 2479 & 4927 \\
\hline
\end{tabular}

*** $\mathrm{p}<0.01, * * \mathrm{p}<0.05, * \mathrm{p}<0.1$

Notes: Dependent Variable is log per capita Expenditure in real terms. Reported coefficients correspond to the Treatment Dummy equaling 0 for observations within the lower bandwidth of the population thresholds, and 1 within the upper bandwidth. All regressions include time fixed effects. Standard errors are robust to heteroskedasticity. 
Table 7: RDD: the effect of population thresholds on government revenue

\begin{tabular}{|c|c|c|c|c|c|c|}
\hline Bandwidth: & $+/-1 \%$ & $+/-2 \%$ & $+/-5 \%$ & $+/-10 \%$ & $+/-15 \%$ & $+/-30 \%$ \\
\hline \multicolumn{7}{|c|}{ Panel A: 1978-2011 } \\
\hline 1st Polynomial & 0.0158 & $0.0783^{* * *}$ & $0.106^{* * *}$ & $0.0935^{* * *}$ & $0.106^{* * *}$ & $0.0424^{* * *}$ \\
\hline 2nd Polynomial & 0.0213 & $0.0973^{* * *}$ & $0.124^{* * *}$ & $0.116^{* * *}$ & $0.120^{* * *}$ & $0.0813^{* * *}$ \\
\hline 3rd Polynomial & 0.0315 & $0.141^{* * *}$ & $0.139^{* * *}$ & $0.115^{* * *}$ & $0.117^{* * *}$ & $0.0835^{* * *}$ \\
\hline 4th Polynomial & 0.0514 & $0.145^{* * *}$ & $0.150^{* * *}$ & $0.111^{* * *}$ & $0.112^{* * *}$ & $0.100^{* * *}$ \\
\hline Observations & 269 & 588 & 1409 & 2823 & 4120 & 7795 \\
\hline \multicolumn{7}{|c|}{ Panel B: 1978-1994 } \\
\hline 1st Polynomial & $-0.178^{* * *}$ & -0.0166 & 0.0363 & $0.0643^{* * *}$ & $0.0732^{* * *}$ & 0.0184 \\
\hline 2nd Polynomial & $-0.188^{* *}$ & -0.0208 & 0.041 & $0.0764^{* * *}$ & $0.0855^{* * *}$ & $0.0448^{* *}$ \\
\hline 3rd Polynomial & $-0.167^{* *}$ & 0.0174 & $0.0590^{*}$ & $0.0806^{* * *}$ & $0.0692^{* * *}$ & $0.0526^{* * *}$ \\
\hline 4th Polynomial & $-0.178^{* *}$ & 0.0808 & 0.0541 & $0.0736^{* *}$ & $0.0675^{* * *}$ & $0.0942^{* * *}$ \\
\hline Observations & 123 & 236 & 615 & 1140 & 1641 & 2868 \\
\hline \multicolumn{7}{|c|}{ Panel C: 1995-2011 } \\
\hline 1st Polynomial & $0.105^{*}$ & $0.127^{* * *}$ & $0.156^{* * *}$ & $0.114^{* * *}$ & $0.137^{* * *}$ & $0.0575^{* * *}$ \\
\hline 2nd Polynomial & $0.0950^{*}$ & $0.165^{* * *}$ & $0.196^{* * *}$ & $0.140^{* * *}$ & $0.146^{* * *}$ & $0.108^{* * *}$ \\
\hline 3rd Polynomial & $0.131^{* *}$ & $0.193^{* * *}$ & $0.197^{* * *}$ & $0.141^{* * *}$ & $0.153^{* * *}$ & $0.100^{* * *}$ \\
\hline 4th Polynomial & $0.134^{* *}$ & $0.207^{* * *}$ & $0.213^{* * *}$ & $0.148^{* * *}$ & $0.149^{* * *}$ & $0.104^{* * *}$ \\
\hline Observations & 146 & 352 & 794 & 1683 & 2479 & 4927 \\
\hline
\end{tabular}

*** $\mathrm{p}<0.01, * * \mathrm{p}<0.05, * \mathrm{p}<0.1$

Notes: Dependent Variable is log per capita Revenue in real terms. Reported coefficients correspond to the Treatment Dummy equaling 0 for observations within the lower bandwidth of the population thresholds, and 1 within the upper bandwidth. All regressions include time fixed effects. Standard errors are robust to heteroskedasticity. 
Table 8: Diff-in-disc: the effect of direct democracy (1995) reform on expenditure

\begin{tabular}{lcccccc}
\hline \hline $\begin{array}{l}\text { Bandwidth: } \\
\text { Sample: 1978-2011 }\end{array}$ & $+/-1 \%$ & $+/-2 \%$ & $+/-5 \%$ & $+/-10 \%$ & $+/-15 \%$ & $+/-30 \%$ \\
\hline 1st Polynomial & 0.0544 & 0.085 & $0.0818^{* *}$ & $0.0812^{* * *}$ & 0.0244 & -0.00364 \\
2nd Polynomial & 0.0188 & 0.0945 & $0.0753^{* *}$ & $0.0787^{* * *}$ & 0.0239 & -0.00207 \\
3rd Polynomial & 0.0211 & 0.0708 & $0.0755^{* *}$ & $0.0793^{* * *}$ & 0.024 & -0.00191 \\
4th Polynomial & -0.00911 & 0.0637 & $0.0741^{* *}$ & $0.0796^{* * *}$ & 0.024 & -0.00255 \\
\hline Observations & 269 & 588 & 1409 & 2823 & 4120 & 7795 \\
\hline \hline
\end{tabular}

$* * * \mathrm{p}<0.01,{ }^{* *} \mathrm{p}<0.05,{ }^{*} \mathrm{p}<0.1$

Notes: Dependent Variable is log per capita Expenditure in real terms. Reported coefficients correspond to the interaction term between the the Treatment Dummy (equaling 0 for observations within the lower bandwidth of the population thresholds, and 1 within the upper bandwidth) and the 1995 Dummy (equaling 1 for the years 1995 and above, and 0 otherwise). All regressions include time fixed effects. Standard errors are robust to heteroskedasticity.

Table 9: Diff-in-disc: the effect of direct democracy (1995) reform on revenue

\begin{tabular}{lcccccc}
\hline \hline $\begin{array}{l}\text { Bandwidth: } \\
\text { Sample: 1978-2011 }\end{array}$ & $+/-1 \%$ & $+/-2 \%$ & $+/-5 \%$ & $+/-10 \%$ & $+/-15 \%$ & $+/-30 \%$ \\
\hline 1st Polynomial & 0.0694 & $0.104^{*}$ & $0.0970^{* * *}$ & $0.0941^{* * *}$ & $0.0397^{* *}$ & 0.00481 \\
2nd Polynomial & 0.0316 & $0.114^{*}$ & $0.0909^{* * *}$ & $0.0920^{* * *}$ & $0.0394^{* *}$ & 0.00657 \\
3rd Polynomial & 0.0297 & 0.0883 & $0.0874^{* * *}$ & $0.0915^{* * *}$ & $0.0393^{* *}$ & 0.00671 \\
4th Polynomial & -0.000635 & 0.0871 & $0.0875^{* * *}$ & $0.0918^{* * *}$ & $0.0394^{* *}$ & 0.00617 \\
\hline Observations & 269 & 588 & 1409 & 2823 & 4120 & 7795 \\
\hline \hline
\end{tabular}

$* * * \mathrm{p}<0.01,{ }^{* *} \mathrm{p}<0.05,{ }^{*} \mathrm{p}<0.1$

Notes: Dependent Variable is log per capita Expenditure in real terms. Reported coefficients correspond to the interaction term between the the Treatment Dummy (equaling 0 for observations within the lower bandwidth of the population thresholds, and 1 within the upper bandwidth) and the 1995 Dummy (equaling 1 for the years 1995 and above, and 0 otherwise). All regressions include time fixed effects. Standard errors are robust to heteroskedasticity. 
Table 10: Robustness of DiD: the effect of direct democracy (1995) reform on fiscal variables at different population threshold separately

\begin{tabular}{|c|c|c|c|c|c|c|}
\hline \multirow{2}{*}{$\begin{array}{l}\text { Population Threshold: } \\
\text { Bandwidth: }\end{array}$} & \multicolumn{2}{|c|}{10 Thousand } & \multicolumn{2}{|c|}{20 Thousand } & \multicolumn{2}{|c|}{30 Thousand } \\
\hline & $+/-5 \%$ & $+/-10 \%$ & $+/-5 \%$ & $+/-10 \%$ & $+/-5 \%$ & $+/-10 \%$ \\
\hline \multicolumn{7}{|l|}{ Panel A: Expenditure } \\
\hline Treatment*Dummy95 & 0.0642 & $0.125^{* * *}$ & 0.0782 & -0.0277 & -0.0191 & $0.128^{* * *}$ \\
\hline St. Err. & -0.044 & -0.0327 & -0.0608 & -0.0373 & -0.0846 & -0.0479 \\
\hline Observations & 861 & 1712 & 320 & 767 & 137 & 397 \\
\hline R-squared & 0.144 & 0.128 & 0.255 & 0.2 & 0.269 & 0.202 \\
\hline \multicolumn{7}{|l|}{ Panel B: Revenue } \\
\hline Treatment*Dummy95 & $0.0902^{* *}$ & $0.125^{* * *}$ & 0.0726 & -0.0277 & -0.00021 & $0.128^{* * *}$ \\
\hline St. Err. & -0.0425 & -0.0327 & -0.0598 & -0.0373 & -0.0801 & -0.0479 \\
\hline Observations & 861 & 1712 & 320 & 767 & 137 & 397 \\
\hline R-squared & 0.148 & 0.128 & 0.25 & 0.2 & 0.3 & 0.202 \\
\hline
\end{tabular}

*** $\mathrm{p}<0.01,{ }^{* *} \mathrm{p}<0.05, * \mathrm{p}<0.1$

Notes: Dependent Variable is the fiscal variables of interest specified for each panel. Reported coefficients correspond to the interaction term between the the Treatment Dummy (equaling 0 for observations within the lower bandwidth of the population thresholds, and 1 within the upper bandwidth) and the 1995 Dummy (equaling 1 for the years 1995 and above, and 0 otherwise). All regressions include time fixed effects. Standard errors are robust to heteroskedasticity. 
Table 11: RDD- do signature and quorum requirements really matter?

\begin{tabular}{lcccccc}
\hline \hline $\begin{array}{l}\text { Bandwidth: } \\
\text { Variable: }\end{array}$ & $+/-5 \%$ & $\begin{array}{c}+/-10 \% \\
\text { Initiative }\end{array}$ & $+/-15 \%$ & $+/-5 \%$ & $+/-10 \%$ & $+/-15 \%$ \\
Referendum & \\
\hline 1st Polynomial & 0.32 & 0.16 & 0.211 & 0.491 & 0.418 & $0.526^{*}$ \\
2nd Polynomial & 0.00835 & -0.0112 & 0.0938 & 0.416 & 0.381 & 0.489 \\
3rd Polynomial & 0.0672 & 0.0334 & 0.0566 & 0.527 & 0.515 & 0.499 \\
4th Polynomial & 0.201 & 0.2 & 0.00531 & 0.715 & $0.702^{*}$ & 0.469 \\
\hline Observations & 794 & 1683 & 2479 & 749 & 1683 & 2479 \\
\hline \hline
\end{tabular}

*** $\mathrm{p}<0.01,{ }^{* *} \mathrm{p}<0.05,{ }^{*} \mathrm{p}<0.1$

Notes: Dependent variable is a dummy when at least one initiative (alternatively: referendum) has happened in that year-town. Reported coefficients correspond to the Treatment Dummy equaling 0 for observations within the lower bandwidth of the population thresholds, and 1 within the upper bandwidth. All regressions include time fixed effects. Standard errors are robust to heteroskedasticity. 


\section{References}

Ade, F. and R. Freier (2011). When can we trust population thresholds in regression discontinuity designs? Discussion Paper 1136, DIW Berlin.

Angrist, J. D. and J.-S. Pischke (2010). The credibility revolution in empirical economics: How better research design is taking the con out of econometrics. Journal of Economic Perspectives 24(2), 3-30.

Bails, D. and M. A. Tieslau (2000). The impact of fiscal constitutions on state and local expenditures. Cato Journal 20, 255-277.

Baskaran, T. (2012). The flypaper effect: evidence from a natural experiment in Hesse. Working Paper 37144, MPRA.

Baumol, W. J. and W. G. Bowen (1966). Performing arts: the economic dilemma. The Twentieth Century Fund.

Bayerisches Landesamt für Statistik und Datenverarbeitung (2013). Gemeindefinanzen und Realsteuervergleich in Bayern 2012, Ergebnisse der vierteljährlichen Kassenstatistik. Technical report, München.

Besley, T. and A. Case (2003). Political institutions and policy outcomes: evidence from the United States. Journal of Economic Literature 41, 7-73.

Besley, T. and S. Coate (1998). Sources of inefficiency in a representative democracy. American Economic Review 88, 139-156.

Blomberg, S., G. Brock, D. Hess, and A. Weerapana (2004). The impact of voter initiatives on economic activity. European Journal of Political Economy 20(1), 207-226.

Blume, L., T. Döring, and S. Voigt (2011). Fiscal effects of reforming local constitutions: recent German experiences. Urban Studies 48(10), 2123-2140. 
Brennan, G. and J. Buchanan (1980). The power to tax: analytical foundations of a fiscal constitution. Cambridge University Press.

Camobreco, J. F. (1998). Preferences, fiscal policies, and the initiative process. Journal of Politics 60, 819-829.

Dahlberg, M., E. Mörk, J. Rattso, and H. Agren (2008). Using a discontinous grant rule to identify the effect of grants on local taxes and spending. Journal of Public Economics 92, 2320-2335.

Debrun, X., L. Moulin, A. Turrini, J. A. i Casals, and M. S. Kumar (2008). Tied to the mast? National fiscal rules in the European Union. Economic Policy 23(54), 297-362.

Eder, C., A. Vatter, and M. Freitag (2009). Institutional design and the use of direct democracy: evidence from the German Länder. West European Politics 32(3), 611633.

Egger, P. and M. Köthenbürger (2010). Government spending and legislative organization: quasi-experimental evidence from Germany. American Economic Journal: Applied Economics 2, 200-212.

Farnham, P. G. (1990). The impact of citizen influence on local government expenditures. Public Choice 64, 201-212.

Feld, L. P., Z. Hessami, and L. Reil (2011). Direkte Demokratie in der Bundesrepublik Deutschland? In Jahrbuch für direkte Demokratie,, pp. 107-134. Baden-Baden: Nomos.

Feld, L. P. and G. Kirchgässner (2001). The political economy of direct legislation: direct democracy and local decision-making. Economic Policy 16, 329-367.

Feld, L. P. and J. G. Matsusaka (2003). Budget referendums and government spending: evidence from the Swiss cantons. Journal of Public Economics 87(12), 2703-2724. 
Feld, L. P., C. A. Schaltegger, and J. Schnellenbach (2008). On government centralization and fiscal referendums: a theoretical model and evidence from Switzerland. European Economic Review 52, 611-645.

Funk, P. and C. Gathman (2011). Does direct democracy reduce the size of government? New evidence from historical data, 1890-2000. Economic Journal 121, 1252-1280.

Gagliarducci, S. and T. Nannicini (2013). Do better paid politicians perform better? Disentangling incentives from selection. Journal of the European Economic Association 92(2), 369-398.

Galletta, S. and M. Jametti (2012). How to tame two Leviathans? Revisiting the effect of direct democracy on local public expenditure. Working Paper 3982, CESifo.

Grembi, V., T. Nannicini, and U. Troiano (2012). Policy responses to fiscal restraints: a difference-in-discontinuities design. Working Paper 3999, CESifo Group Munich.

Hallerberg, M., R. Strauch, and J. von Hagen (2007). The design of fiscal rules and forms of governance in European Union countries. European Journal of Political Economy 23(2), 338-359.

Hinnerich, B. T. and P. Pettersson-Lidbom (2012). Democracy redistribution and political participation: evidence from Sweden 1919-1938. Working paper, Stockholm University.

Holtkamp, L., J. Bogumil, and L. Kißler (2006). Kooperative Demokratie: Das politische Potenzial von Bürgerengagement. Frankfurt: Campus Verlag.

Imbens, G. W. and T. Lemieux (2008). Regression discontinuity designs: a guide to practice. Journal of Econometrics 142(2), 615-635.

Inman, R. P. (1998). Do balanced budget rules work? US experience and possible lessons for the EMU. Working Paper 5838, NBER.

Kenny, L. W. (1978). The collective allocation of commodities in a democratic society: a generalization. Public Choice 33, 117-120. 
Lee, D. S. (2008). Randomized experiments from non-random selection in us house elections. Journal of Econometrics 142(2), 675-697.

Marschall, M. J. and A. Ruhil (2005). Fiscal effects of the voter initiative reconsidered: Addressing endogeneity. State Politics and Policy Quarterly 5(4), 327-255.

Matsusaka, J. G. (1995). Fiscal effects of the voter initiative: evidence from the last 30 years. Journal of Political Economy 103, 587-623.

Matsusaka, J. G. (2000). Fiscal effect of the voter initiatives in the first half of the twentieth century. Journal of Law and Economics 43, 619-650.

McCrary, J. (2008). Manipulation of the running variable in the regression discontinuity design: a density test. Journal of Econometrics 142, 698-714.

Meltzer, A. H. and S. F. Richard (1981). A rational theory of the size of government. Journal of Political Economy 89(5), 914-927.

Niskanen, A. W., M. Bronfenbrenner, and R. D. Tollison (1980). The prospect for liberal democracy. In J. M. Buchanan and R. E. Wagner (Eds.), Fiscal responsibility in constitutional democracy, pp. 157-180. Dordrecht, Netherlands: Kluwer Academic Publishing.

Niskanen, W. (1971). Bureaucracy and representative government. New-York: AldineAtherton.

Persson, T. and G. Tabellini (2004). Constitutional rules and fiscal policy outcomes. American Economic Review 94(1), 25-45.

Pettersson-Lidbom, P. (2012). Does the size of the legislature affect the size of the government: evidence from two natural experiments. Journal of Public Economics 96, 269-278.

Pommerehne, W. (1978). Institutional approaches to public expenditures: empirical evidence from Swiss municipalities. Journal of Public Economics 9, 255-280. 
Premat, C. (2006). The transformation of local democracy through the use of semi-direct democracy procedures in France and Germany. Working paper, World Congress of the International Political Science Association, Fukuoka, Japan.

Primo, D. M. (2010). The effect of initiatives on local government spending. Journal of Theoretical Politcs 22, 6-25.

Salvino, R., M. T. Tasto, and G. K. Turnbull (2012). A direct test of direct democracy: New England town meetings. Applied Economics 44, 2393-2402.

Scarrow, S. E. (1999). Parties and the expansion of direct democracy: who benefits? Party Politics 5(3), 356-357.

Schaltegger, C. and L. P. Feld (2009). Are fiscal adjustments less successful in decentralized governments? European Journal of Political Economy 25(1), 115-123.

Setala, M. and T. Schiller (2012). Citizens' initiatives in Europe: procedures and consequences of agenda-setting by citizens. New York: Palgrave MacMillan.

Shepsle, K. A. and B. R. Weingast (1981). Political preferences for the pork barrel: a generalization. American Journal of Political Science 25(1), 96-111.

Thistlewaite, D. and D. Campbell (1960). Regression-discontinuity analysis: an alternative to the ax-post facto experiment. Journal of Educational Psychology 51, 309-317.

Verhulst, J. and A. Nijeboer (2008). Direct democracy: facts and arguments about the introduction of initiative and referendum. Brussels: Democracy International.

von Hagen, J. (2002). Fiscal rules, fiscal institutions, and fiscal performance. The Economic and Social Review 33(3), 263-284.

Weingast, B. R., K. A. Shepsle, and C. Johnsen (1981). The political economy of benefits and costs: a neoclassical approach to distributive politics. Journal of Political Economy 89(4), 642-664. 
Zax, J. S. (1989). Initiatives and government expenditures. Public Choice 63, 267-277. 